\title{
Que Democracia? Uma Visão Conceitual desde a Perspectiva dos Países em Desenvolvimento*
}

\author{
Maria Helena de Castro Santos
}

\section{INTRODUÇão}

I esmo a um observador iniciante não escapam dois grandes movimentos globais das duas últimas décadas: democratização e profunda integração econômica. Para o mundo em desenvolvimento, integração econômica exige políticas de ajuste e reforma econômica, inflexivelmente definidas pelas agências multilaterais de desenvolvimento. Diante dessa forte pressão externa, qual o grau de autonomia dos países emergentes no que se refere à definição da sua agenda

\footnotetext{
*Este trabalho foi apresentado no seminário internacional Progress \& Challenges of Democratization and Economic Liberalization: South Africa, Nigeria, Brazil, Mexico, Indonesia, Korea, Poland and Hungary, James Madison College, Michigan State University, Lansing, Michigan, 7-9 de abril de 2000. Em versões anteriores, foi apresentado no seminário internacional Política Internacional e Comparada: Perspectivas Recentes no Brasil, Departamento de Relações Internacionais, Universidade de Brasília, Brasília, 11-12 de novembro de 1999 e no XX Encontro Anual da Associação Nacional de Pós-Graduação e Pesquisa em Ciências Sociais - AnPoCs, Caxambu, MG, 24-28 de outubro de 1996, tendo sido reproduzido em Cadernos REL, Departamento de Relações Internacionais, Universidade de Brasília, 1996. O trabalho beneficiou-se muito dos comentários de Maria Regina Soares de Lima, Margaret Keck, Leticia Pinheiro, Brasílio Sallum, Kurt von Mettenheim e Carlos Pio, todos presentes ao seminário de Brasília. Agradeço especialmente aos dois últimos pela leitura cuidadosa das primeiras versões e por seus comentários, sempre pertinentes.
}

DADOS - Revista de Ciências Sociais, Rio de Janeiro, Vol. 44, nํ 4, 2001, pp. 729 a 771. 
econômica? E quanto à democratização? É a democracia, com a derrocada do mundo socialista, "the only game in town"? De que democracia estamos falando? Do modelo de democracia liberal ocidental? É ela aplicável a países de contextos histórico-culturais tão diversos? Não é a democracia expressão da hegemonia ocidental no mundo pósGuerra Fria e, portanto, forma de pressão sobre as nações em desenvolvimento?

Tendo como referência essas questões, este trabalho se divide em quatro partes. Na primeira apresento uma revisão da literatura sobre os processos de democratização e reforma econômica em países em desenvolvimento, chamando a atenção para o tratamento estanque dispensado pelos dois tipos de literatura a esses processos e para pontos que, a meu ver, merecem maior elaboração ou tratamento distinto. Em seguida, refiro-me aos conceitos-chave da literatura sobre democratização e reforma econômica, a saber, governabilidade, governance e democracia, e os vieses normativos implícitos nestes conceitos. Discuto especialmente o conceito de democracia utilizado pelos dois tipos de literatura, baseado no chamado "procedural mínimo", e sua adequação à análise dos regimes emergentes nos países em desenvolvimento. Sugiro a expansão da definição de procedural mínimo para incluir os atributos do processo decisório que se estruturam nos novos ambientes, como um instrumento analítico capaz de distinguir os regimes recentes e avaliar sua capacidade governativa. Na terceira parte, baseada em evidências empíricas de trabalhos anteriores, e a título de ilustração, discuto o padrão de tomada de decisão no Brasil pós-autoritário, avaliando suas características como mais ou menos democráticas. Finalmente, tendo como referência o caso brasileiro, discuto a questão do tipo de regime que os países emergentes poderão desenvolver, formulando indagações provocativas que evidenciam o forte viés normativo pró-democracia da literatura em foco, largamente disseminado nas sociedades tanto desenvolvidas como em desenvolvimento.

\section{A TERCEIRA ONDA E O MODELO DE DEMOCRACIA LIBERAL OCIDENTAL}

A Revolução dos Cravos em Portugal, em 1974, inaugura o que Samuel Huntington $(1991 ; 1996 b)$ chamou de terceira onda de democratização ${ }^{1}$. Utilizando basicamente os indicadores de democracia da Freedom House ${ }^{2}$, a literatura americana enfatiza a onda de democratização que atingiu todos os continentes, em proporção significativa- 
mente maior que as duas anteriores. De fato, na crista da primeira e da segunda ondas de democratização contaram-se 29 e 36 países democráticos, respectivamente, correspondendo a $45,3 \%$ e $32,4 \%$ do total de Estados no mundo. Por outro lado, em 1999, de um total de 192 países, $62,5 \%$ foram considerados formalmente democráticos, ou seja, 120 países tinham, nessa data, sistemas democráticos constitucionais com eleições competitivas e multipartidárias, em contraste com apenas 41\% há uma década (Freedom House, 1999-00; Huntington, 1996b; Diamond, 1999, cap. 2; 2000).

A pergunta básica que direciona essa literatura é se a terceira onda, como as demais, vai atingir um ápice e em seguida declinar ou se estamos diante de um movimento inexorável e definitivo em direção à democracia. Poucos acreditam, como Fukuyama, que a democracia capitalista liberal é o fim absoluto da história, com a exaustão das principais alternativas sistemáticas viáveis ao liberalismo ocidental. Para esse autor, se o desenvolvimento econômico prepara o terreno para a democracia liberal, é no plano da ideologia que se deve procurar a explicação para a terceira onda de democratização. O que importa, diz o autor, é que a população em todo o mundo finalmente se tornou consciente de que somente a democracia liberal torna possível o reconhecimento plenamente racional da dignidade humana, identificando na democracia o único regime legítimo do mundo (cf. Fukuyama, 1989; 1991; 1996).

Raros autores, por outro lado, compartilham do pessimismo de Jowitt (1996). Em visão oposta à de Fukuyama, Jowitt acredita que a "extinção do leninismo" alterou profundamente o quadro de referências do Terceiro Mundo, que passa agora a contar apenas com os parâmetros da civilização liberal capitalista e democrática. Tal "modo de vida" contudo, apesar de única referência no mundo pós-Guerra Fria ${ }^{4}$, não significa em absoluto o fim da história ou a civilização final. Democracia é apenas uma alternativa possível, historicamente rara e de constituição dolorosa. Para ele, o mundo mais provável com a extinção do leninismo é o mundo caótico descrito em Gênesis, onde as fronteiras territoriais, ideológicas e políticas são confusas e incertas, as identidades permanecem em transformação, os líderes são mais importantes do que as instituições e as guerras e os "movimentos de cólera" (movements of rage) são as conseqüências mais prováveis desse novo ambiente internacional ${ }^{5}$. Assim, para Jowitt, seria mais acurado se falar em "longa marcha" do que em transição para a democracia. 


\section{Maria Helena de Castro Santos}

A maior parte da literatura assume posição intermediária entre os dois extremos. De fato, se hoje as democracias liberais são amplamente consideradas como "as únicas sociedades totalmente modernas" (Plattner, 1996:40), raros autores, como Fukuyama, consideram-na a única rota possível para os países em desenvolvimento. Há, assim, uma vasta literatura dedicada à análise das condições e fatores mais favoráveis à promoção e consolidação das democracias emergentes ou, inversamente, das dificuldades e ameaças a esses processos, a partir do que as diversas regiões em que o mundo é dividido por essa literatura - América Latina, países pós-comunistas (Europa Central e do Leste, e países da antiga União Soviética), Leste Asiático, África Subsaariana, países muçulmanos - e os países que as compõem são avaliados. Assim, argumenta-se e contra-argumenta-se quanto aos obstáculos culturais que o islamismo e o confucionismo apresentariam à democratização segundo o modelo ocidental competitivo, da mesma forma que se avalia a aplicabilidade desse modelo de democracia à bem-sucedida alternativa asiática de desenvolvimento única capaz de dominar a tecnologia ocidental moderna e criar economias capitalistas competitivas em ambiente cultural não ocidental ${ }^{6}$. De modo geral, implícita ou explicitamente, todos manifestam a "esperança" de que os sistemas políticos avaliados venham a tornar-se democráticos ou consolidados. O forte viés normativo pró-democracia é inequívoco.

Dessa forma, já que as mudanças culturais são lentas e difíceis, o tempo medindo-se em gerações - por exemplo, a construção ou reconstrução de sociedades baseadas no desenvolvimento da civil society e no sentimento de confiança (trust) entre seus cidadãos (cf. Diamond, 1996b; Rose, 1996; Putnam, 1995) —, há uma concentração de esforços na discussão do desenho institucional das novas democracias ${ }^{7}$. Assim, ocupa lugar central nessa literatura o debate em torno da importância do tipo de sistema de governo, de sistema eleitoral e de sistema partidário para a consolidação e efetivo funcionamento das democracias emergentes, freqüentemente sem se levar em conta o background histórico-cultural e político-institucional do país ou a situação econômica anterior ao processo de democratização. Além do mais, com especial menção à construção de coalizão de suporte governamental e às relações Executivo-Legislativo, analisam-se as vantagens e desvantagens do presidencialismo vis-à-vis o parlamentarismo, em suas diversas combinações com sistemas eleitorais majoritários ou pro- 
porcionais e sistemas multi ou bipartidários. Argumenta-se contra os perigos do presidencialismo, especialmente em nações com profundas clivagens e sistema multipartidário fragmentado e polarizado (Linz) e enfatiza-se a combinação, especialmente benéfica para as novas democracias, entre parlamentarismo e representação proporcional (Lijphart). Contestam-se, não obstante, essas assertivas (Horowitz, Lardeyet e Quade), questionando-se sua validade para universos empíricos mais amplos do que os pesquisados pelos autores (Lipset) $)^{8}$.

De maneira geral, espera-se e mesmo exige-se dos países em desenvolvimento padrões de democracia iguais aos dos países ocidentais avançados, sendo os distintos contextos históricos e culturais, quando levados em conta, considerados obstáculos maiores, mas não intransponíveis. A referência absoluta ao modelo de democracia ocidental é enfatizada por autores que, reconhecendo problemas internos a democracias desse tipo (por exemplo, o declínio da civil society americana ${ }^{9}$ ), advertem para a importância de "corrigir" esses problemas sob pena de "decepcionar" as novas democracias (sobretudo países pós-comunistas), que deixariam de considerar o modelo ocidental como a solução de seus problemas, colocando-as em rota de reversão ao autoritarismo. Nesse sentido, para Król (1996) o futuro da democracia depende muito mais da manutenção dos padrões de democracia nos países avançados ocidentais do que dos processos internos das próprias democracias emergentes.

Parte significativa da literatura sobre democracia até aqui tratada assume postura naïve e missionária, quando não militante, mas certamente ideológica, na defesa e promoção da democracia no mundo, justificando importantes instituições como o National Endowment for Democracy $^{10}$. Por outro lado, como conseqüência do fim da Guerra Fria, e contrapartida já não tão naïve da postura missionária acadêmica, coloca-se a "condicionalidade política" agora imposta pelas agências multilaterais de desenvolvimento - FMI, Banco Mundial - em justaposição à condicionalidade econômica das décadas passadas. De fato, o governo dos Estados Unidos, agora teoricamente livre de suas ambigüidades no mundo bipolar anterior - quando apoiava ditaduras anticomunistas e promovia "democracia por meios antidemocráticos" - , passa a pressionar fortemente os países em desenvolvimento em direção ao sistema político democrático, como parte de sua política externa, com a ajuda da União Européia, do Conselho da 
Europa ou da Organização para Segurança e Cooperação na Europa, da OEA e da ONU (cf. Farer, 1996, e, de uma perspectiva crítica, Król, 1996 e, sobretudo, Schmitter e Santiso, 1997). É importante, portanto, considerar democracia como pressão externa, expressão da hegemonia ocidental, independentemente da preferência dos cidadãos e governantes dos países em tela.

A idéia de modelo ideal de democracia, à moda dos países industrializados ocidentais nos mais diversos ambientes histórico-culturais que compõem o mundo em desenvolvimento, é criticada por parte relevante da literatura recente sobre processo de democratização. Embora a referência comum continue sendo a democracia procedural na tradição de Schumpeter/Dahl, esse segmento da literatura fala de tipos de democracia, de democracia delegativa, graus e limites mínimos de democracia e regimes híbridos, geralmente levando em conta os distintos contextos histórico-culturais das democracias emergentes.

Assim, Schmitter e Karl (1996) sugerem que sistemas políticos em transição democrática podem compor uma matriz de combinações potenciais que sejam diferentemente democráticas. As distintas misturas combinam componentes democráticos que se referem a consenso, participação, acesso, responsiveness, regra majoritária, soberania parlamentar, partido do governo, pluralismo, federalismo, presidencialismo, checks and balances.

O'Donnell (1996a; 1996b; 1997c), por sua vez, propõe, tomando como referencial empírico a América Latina, o termo "democracia delegativa" para caracterizar um novo tipo de democracia, que se distingue das democracias representativas ocidentais. As democracias delegativas, sugere o autor, pressupõem a concepção cesarista e plebiscitária de um presidente eleito que se percebe investido do poder de governar o país da forma como lhe aprouver, constrangido apenas pelas relações de poder existentes e o tempo constitucionalmente limitado de seu mandato. Esse tipo de democracia combina eleições livres, competitivas e formalmente institucionalizadas com instituições políticas não formalizadas, com destaque para o clientelismo e, de forma mais ampla, o particularismo (onde não há distinção comportamental, legal e normativa entre a esfera pública e a privada). As afinidades eletivas entre o particularismo, a reduzida "prestação de contas horizontal" (entre as agências públicas), a pouca transparência dos processos de tomada de decisão das políticas governamentais, a

\section{4}


grande distância entre as normas formais e o funcionamento concreto da maioria das instituições políticas e as concepções e práticas delegativas, não representativas de autoridade política, terminam por reviver e acentuar características do antigo autoritarismo.

Ainda tendo como referencial a América Latina, Malloy (1993) prevê, na década de 90, o surgimento de novos regimes híbridos, nos quais os elementos de estilo autoritário de política serão fundidos com processos eleitorais democráticos. Nesses híbridos, a questão crucial será se e como as expressões organizadas da sociedade civil serão integradas ao processo de governo e de elaboração de políticas públicas, e qual o papel que os partidos políticos desempenharão enquanto mediadores desse tipo de articulação.

As concepções de O'Donnell e Malloy acerca das novas democracias latino-americanas apontam, em comum, para regimes políticos que combinam eleições democráticas institucionalizadas e práticas autoritárias, embora só o segundo utilize o rótulo de regimes híbridos. Este é também usado por Karl (1995) ao analisar os novos regimes da América Central. Para esta autora, regimes híbridos referem-se a uma certa mistura política, tanto funcional como territorial, que expressa uma aquisição desigual dos requisitos procedurais da democracia nos países em foco. Em trabalho anterior, O'Donnell e Schmitter (1986), embora se referindo mais especificamente ao contexto de transição democrática, também lançam mão da idéia de regimes híbridos, aos quais chamam de dictablandas e democraduras.

Król (1996), finalmente, confronta-nos com a pergunta essencial se a democracia liberal possui ambição e relevância universais ou, ainda, se o choque de civilizações (clash of civilizations) de Huntington (1996a) é inevitável. Lembrando que democracia imposta não funciona, Król sugere que a saída é estarmos preparados teoricamente para falarmos de graus de democracia. Devemos concordar, continua o autor, em definir um limite mínimo de democracia e aceitar que diferentes países, com diferentes civilizações, diferentes religiões, mores e tradições adotem práticas inaceitáveis em nossas próprias civilizações.

\section{DEMOCRACIA E REFORMA ECONÔMICA}

Outro ponto que chama a atenção na literatura recente sobre transição e consolidação democrática é a ausência da dimensão econômica 


\section{Maria Helena de Castro Santos}

nas análises produzidas. Choques externos atingiram duramente vários países e contribuíram para recessão e instabilidade macroeconômica ao longo dos anos 80 , chegando em muitos casos à década seguinte. Como resposta a esses choques, profundas mudanças nas estratégias de desenvolvimento em direção a políticas econômicas orientadas para o mercado foram operadas, tais como liberalização do comércio e atração de investimento externo. O ritmo da liberalização econômica varia entre os países, mas a direção da mudança da política econômica - definida e fortemente reforçada pelas agências multilaterais de desenvolvimento - vem sendo inequivocamente traçada. Apesar disso, as políticas de ajuste, quando mencionadas por essa literatura, são tomadas como dadas, sem que se discuta em profundidade, para além dos constrangimentos eleitorais, suas implicações para os regimes democráticos emergentes (ver, p. ex., Diamond, 1996a). Sem dúvida, a associação positiva entre desenvolvimento econômico e democracia é plenamente reconhecida ${ }^{11}$, mas não se vai muito além disso. Haggard e Kaufman ${ }^{12}$ chamam a atenção para o viés institucionalista dessa literatura: "[...] é um erro relegar as dimensões econômica e política a esferas de análise separadas; condições econômicas e política governamental, tanto quanto a natureza das instituições políticas, condicionam os prospectos da democracia" (1995:4, tradução livre).

A literatura de reforma econômica e reforma do Estado, ao contrário daquela sobre democratização, analisa de forma inter-relacionada as dimensões econômica e política das políticas de ajuste. Haggard e Kaufman sugerem, assim, que: "O curso tanto da mudança de regime como da elaboração da política econômica é determinado, em última instância, pelas escolhas estratégicas dos atores-chave - os que apóiam e os que se opõem ao governo - enquanto constrangidos pelas circunstâncias econômicas e pelas instituições existentes" (idem:5, tradução livre).

Escolhas e constrangimentos são, portanto, elementos do modelo teórico-analítico proposto pelos autores, a partir dos quais as variáveis econômicas, políticas e institucionais são combinadas para explicar as resultantes (outcomes) dos processos de democratização e das reformas orientadas para o mercado.

As questões e "consensos" da literatura de reforma do Estado refletem a concepção teórico-metodológica explicitada por Haggard e

\section{6}


Que Democracia? Uma Visão Conceitual desde a Perspectiva dos Países...

Kaufman. Assim, brevemente, o consenso (common wisdom) dos anos 80 assumia, a partir das experiências de Chile, China, México e Leste Asiático, que regimes autoritários tinham nítidas vantagens, vis-à-vis as novas democracias, na promoção de políticas de estabilização e liberalização econômica porque eram capazes de controlar, ignorar ou reprimir os grupos sobre os quais recairiam os custos das reformas. A ordem recomendada de implementação das políticas governamentais (path sequence) era, então, primeiro ajustar e liberalizar a economia e só então liberalizar e democratizar o sistema político. O "consenso" da década de 80 , contudo, tem sido questionado, já que países com regimes autoritários, tais como Peru, Filipinas, Uganda, Zâmbia e Zaire, demonstraram má performance, enquanto novas democracias, tais como Argentina (sic), Bolívia, Polônia e República Checa, ao contrário, tinham mostrado significativo progresso na condução de reformas econômicas orientadas para o mercado (Diamond e Plattner, 1996c). Maravall (1995) e Geddes (1995) estão entre os principais críticos dessa concepção. O primeiro sugerindo variáveis explicativas para o sucesso ou fracasso das reformas, independentemente do tipo de regime político - condições internas, tais como existência de crise econômica, experiências passadas de política econômica, natureza das instituições políticas e pressões internacionais. A segunda trazendo novas evidências empíricas, fazendo críticas metodológicas a estudos que geraram o criticado "consenso dos 80 ", além de destacar a importância dos "atores governamentais", de políticos em cargos executivos e da liderança política para a mobilização de interesses pró-reforma.

Assim, na década de 90, as preocupações com o path sequence mudam para questões tais como os arranjos político-institucionais mais capazes de promover as políticas de ajuste econômico, os imperativos e constrangimentos das diferentes fases desse processo e o grau em que procedimentos democráticos devem ser modificados para facilitar a reforma econômica. Emerge, então, novo consenso. A primeira fase das políticas de ajuste, que inclui estabilização e alguma liberalização de preço e comércio, requer Executivos fortes e uma pequena equipe técnica insulada de pressões políticas. Apesar de técnica e politicamente difícil, nessa fase os custos são mais difusamente espalhados entre a população. A segunda etapa, que inclui reforma do setor financeiro, privatização, liberalização dos mercados de trabalho, reestruturação e ampliação das redes de proteção social e reforma admi- 
nistrativa, representa desafios muito maiores, já que se explicitam os grupos sociais ganhadores e os perdedores. Colocam-se, então, duros trade-offs entre a progressão dos programas de reforma e a intensificação de conflitos de interesse. A mobilização de uma coalizão pró-reforma exige não só resultados, como também a construção de canais de intermediação, consulta e negociação entre os interesses envolvidos, para o que não se prescinde de métodos e lideranças democráticos (ver, p. ex., Haggard e Kaufman, 1994; 1995; Nelson, 1995; Remmer, 1986). Embora essa literatura enfatize o papel dos partidos políticos na construção dessa delicada tecitura social e política, ela não deixa de considerar e avaliar a possibilidade da construção de arranjos corporativos do tipo europeu social-democrata (cf. Haggard e Kaufman, 1995). O quadro se complexifica significativamente quando os países enfrentam a chamada "transição dual" (reforma econômica e abertura política ocorrendo ao mesmo tempo) e/ou "superposição das fases" da reforma econômica ${ }^{13}$.

A literatura sobre reforma econômica, dessa forma, busca construir proposições que vinculem padrões de decisão das políticas de ajuste com as fases desse processo, procurando estabelecer conseqüências para a consolidação da democracia, admitindo, inclusive, institucionalidades democráticas que se afastam dos procedimentos clássicos do modelo ocidental liberal competitivo. Entretanto, as análises do ponto de vista político-institucional desse veio da literatura não mostram a mesma sofisticação e profundidade que as análises da literatura de democratização.

Uma forma de proceder a um estudo mais holístico dos processos de transição econômica e política dos países em desenvolvimento é recorrer aos conceitos de governabilidade e governance. Ambos, juntamente com o de democracia, formam o núcleo conceitual das literaturas de reforma econômica e democratização. Procede-se, na seção seguinte, a um exame crítico dos mesmos, sugerindo-se uma estratégia metodológica que explicite os vieses normativos da análise.

\section{GOVERNABILIDADE, GOVERNANCE, CAPACIDADE GOVERNATIVA E DEMOCRACIA}

Os conceitos identificam disciplinas científicas e delineiam suas fronteiras ou, dizendo de outra forma, as disciplinas definem sua identidade através de seus conceitos-chave. De acordo com Sartori, concei-

\section{8}


Que Democracia? Uma Visão Conceitual desde a Perspectiva dos Países...

tos não são apenas elementos de um sistema teórico, mas são, igualmente, data containers (Sartori, 1970). Os conceitos são, portanto, instrumentos da investigação empírica, uma espécie de processadores da informação coletada. Em nome da boa comunicação entre pesquisadores de uma disciplina, deve existir um consenso mínimo sobre seus conceitos significativos.

O mesmo se aplica a subdisciplinas. Embora exista controvérsia sobre a existência do que Schmitter (cf., entre outros, Schmitter e Karl, s/d) chama de "transitologia" e "consolidologia", o estudo das transições política e econômica dos países emergentes requer uma linguagem conceitual comum. Em anos recentes, a literatura sobre democratização e reforma econômica vem tentando construir essa linguagem comum através da revisão crítica dos conceitos de governabilidade, governance e democracia. Esse processo de reconstrução conceitual (cf. Sartori, 1970) é conseqüência necessária das profundas transformações globais dos últimos vinte anos, que incluem o reordenamento do sistema internacional, a expansão da democracia por todos os continentes em proporção e velocidade sem precedentes, a profunda integração financeira e econômica do mundo, e suas conseqüências nos planos doméstico e regional. Os "comparativistas" enfrentam, portanto, o desafio de reconstruir os containers conceituais do campo, de forma a compreender as experiências recentes dos países em desenvolvimento no mundo pós-transições e pós-Guerra Fria.

\section{Governabilidade, Governance e Capacidade Governativa}

Estudos recentes de reforma econômica e do Estado evolvem em torno dos conceitos de governabilidade e governance, os quais se referem à performance governamental, eficácia e processo decisório, ajudando a avaliar a capacidade política, institucional e gerencial do governo para promover um desenvolvimento socioeconômico sustentável.

Há uma profusa literatura nos países em desenvolvimento que discute a utilidade analítica desses conceitos e sua correta interpretação. Eu mesma discuti detalhadamente (Castro Santos, 1997) o seu uso, tomando como referência o trabalho de estudiosos brasileiros. Dessa discussão, destaco aqui a questão dos vieses normativos embutidos nos dois conceitos. Assim, enquanto a noção de governabilidade tem suas raízes na concepção huntingtoniana de fortalecimento das instituições e da autoridade governamental para enfrentar sobrecarga de 


\section{Maria Helena de Castro Santos}

demanda da sociedade, o termo governance tem sido utilizado em anos recentes pelas agências multilaterais de financiamento (FMI, Banco Mundial) para referir-se à maneira pela qual o poder é exercido no gerenciamento dos recursos econômicos e sociais do país para o desenvolvimento (World Bank, 1992). O bom governo (good governance) prevê o exercício do poder de forma a promover desenvolvimento sustentável, eqüidade socioeconômica e a garantia dos direitos humanos. O viés normativo implícito é o que considera a democracia como requisito indispensável para o bom governo. Assim, se o remédio prescrito por Huntington para a crise de governabilidade em países em desenvolvimento na era pós-Guerra Fria era o autoritarismo ${ }^{14}$, a rota de sucesso para o desenvolvimento no mundo pósbipolar é democrática. Dessa forma, o conceito de governance, como usado na literatura recente de reforma econômica, vincula eficácia e processo decisório democrático ${ }^{15}$.

Considerações sobre os vieses normativos à parte, vale notar que os conceitos de governabilidade e governance têm sido freqüentemente usadas pela literatura de forma intercambiável, ou, pior, um grande número de estudiosos tem sugerido adicionar ou retirar elementos às definições de ambas com o objetivo de diferenciá-las. A fim de impedir essa confusão, sugeri o uso da noção de capacidade governativa. Além do mais, o caráter operacional do conceito proposto ajuda a evitar julgamentos de valor sobre os regimes em construção nos países emergentes. Esta noção de capacidade governativa, essencialmente apoiada em decision-making, inclui também as dimensões política, econômica e gerencial do governo. Diz-se que um governo tem capacidade governativa quando é capaz de

"[...] produzir políticas públicas que resolvam os problemas da sociedade, ou dizendo de outra forma, de converter o potencial político de um dado conjunto de instituições e práticas políticas em capacidade de definir, implementar e sustentar políticas. [...] Tanto os processos de formulação como os de implementação de políticas públicas são elementos cruciais constitutivos da capacidade governativa do Estado. A formulação bem-sucedida de políticas públicas depende, de um lado, do sucesso de a elite governamental mobilizar apoios para as políticas de sua preferência mediante a formação de coalizões de sustentação e, de outro, da construção de arenas de negociação que evitem a paralisia decisória. O bom êxito do processo de implementação 
exige, além de coalizões de apoio ao governo, capacidade financeira, instrumental e operacional do Estado" (Castro Santos, 1997:344).

Minha proposta metodológica desdobra-se em dois passos. O primeiro refere-se à investigação dos processos de tomada de decisão das políticas públicas, especialmente das políticas de ajuste, que dominam invariavelmente a agenda governamental dos países emergentes. Aqui a tarefa é identificar os padrões e características desses processos e avaliar o sucesso ou fracasso das políticas e planos do governo, estimando, assim, sua capacidade governativa, independentemente de julgamento de valor sobre o regime em construção. Na segunda fase da análise podemos adicionar o requisito democrático à capacidade governativa, isto é, independentemente de considerações sobre a existência ou não de trade-offs entre eficácia e democracia, podemos preferir, ideologicamente, a rota democrática para o desenvolvimento. Nesta fase, tarefas relevantes são, por exemplo, explorar como as liberalizações econômica e política interagem mutuamente e, mais especificamente, avaliar as tensões que os resultados das políticas governamentais podem imprimir ao processo de democratização como um todo. Neste ponto, é crucial examinar o conceito de democracia adotado pela literatura recente.

\section{Democracia}

A grande maioria dos autores da literatura de democratização adota, na tradição Schumpeter/Dahl, a definição procedural mínima de democracia. Esta se refere basicamente a eleições livres, honestas e competitivas, a direitos civis e direitos políticos.

Tem sido argüido, contudo, que o procedural mínimo é mínimo demais. Terry Karl (1995) adverte contra a "falácia do eleitoralismo", lembrando que eleições e partidos políticos nem sempre são suficientes para constituir democracias. Analisando a América Central, Karl observa que, embora as eleições possam ser um importante passo para a expansão dos direitos civis, da igualdade política, participação, contestação e prestação de contas podem também ser indicativas de um novo ciclo de liberalização seguido de repressão e autoritarismo. A literatura tenta escapar deste problema acrescentando atributos ao procedural mínimo ${ }^{16}$. Dessa forma, muitos autores "precisam" essa definição de democracia, adicionando-lhe novos "atributos definidores" (cf. Collier e Levitsky, 1997). Karl (1990), por exemplo, base- 
ada na experiência latino-americana, inclui na definição de democracia, prerrogativas militares limitadas. Schmitter e Karl (1996) adicionam um outro atributo ao procedural mínimo, relativo à autodeterminação do sistema político. Este deve ser capaz de agir de forma independente, a salvo de constrangimentos impostos por algum outro sistema político. Eles também refraseiam a condição formulada por Karl (1990) em termos mais gerais, indicando que governantes eleitos não devem sofrer restrições severas ou ter suas decisões submetidas ao veto de atores não eleitos, como servidores civis arraigados ao cargo ou gerentes de empresas estatais, e especialmente os militares. O'Donnell (1997c) incorpora esta última condição, assim como o requerimento adicionado por Linz e Stepan (1996), da existência de um território não disputado que claramente identifique os eleitores, acrescentando mais dois atributos definidores de democracia: governantes escolhidos por meio de eleições livres e competitivas não devem ser afastados do cargo antes do final do mandato constitucionalmente estabelecido, e a existência de uma expectativa generalizada de que o processo de eleições limpas e as liberdades civis que as acompanham irão durar indefinidamente.

A questão de se trabalhar com o procedural mínimo ou com o procedural mínimo expandido suscita a importante questão da linha divisória (cut-off line) entre regimes democráticos e não democráticos. Onde parar? Qual deverá ser o último atributo que, acrescentado à definição procedural mínima de democracia e cumprido pelos novos regimes, permitirá classificá-los como democráticos? ${ }^{17}$

O conceito de democracia que aqui proponho para a análise do processo de consolidação democrática dos países em desenvolvimento, também adota e vai além do procedural mínimo, mas para incluir, de uma perspectiva diferente da lista de Dahl expandida, representação e processo de decisão.

Poucos autores trabalham com essa perspectiva. De fato, a literatura de democratização enfatiza o papel das elites na mudança de regime, centrando seu foco no incerto resultado do jogo político entre coalizões pró e antidemocráticas. Fala-se, então, em duros e brandos do regime autoritário, moderados e radicais da oposição ao regime (O'Donnell e Schmitter, 1986). Entre os atores estratégicos, que iniciam ou reagem à mudança de regime, estão militares, empresários e trabalhadores (estes últimos, em geral, considerados menos relevan- 
tes, mas cf. Collier, 1999). Uma vez formalmente instalada a democracia - quando o chamado procedural mínimo (Schumpeter/Dahl) é atingido - , essa literatura passa a investigar a associação entre, de um lado, os modos de transição democrática (por ruptura, por transação, por liberalização (extrication), cf. Mainwaring, 1992; Share e Mainwaring, 1988), os legados autoritários (Hagopian, 1992; 1996) e culturais (Huntington, 1996a; 1996b), o grau de controle dos militares sobre o novo regime (Diamond e Plattner, 1996a; Aguero, 1992; 1997; Rial, 1992; Hunter, 1997), o desenho institucional do novo regime (Lijphart, 1996a; 1996b; Linz, 1996a; 1996b; Horowitz, 1996; Quade, 1996; Lipset, 1996), e, de outro, a consolidação da democracia. Pouca atenção, porém, é prestada aos padrões de tomada de decisão que se configuram nas novas democracias e à forma de inserção e controle exercidos pelos atores estratégicos.

Malloy (1993:101) é uma das poucas exceções (cf., também, Conaghan, 1992). Para este autor, democracia deveria ser vista como um processo contínuo de formulação de políticas governamentais, em que a questão central é a relação estruturada entre os principais grupos da sociedade civil (especialmente sindicatos de trabalhadores e empresários) e o processo de formação de políticas governamentais. Atenção exagerada, diz Malloy, tem sido posta em eleições livres e competitivas, partidos políticos e direitos civis, negligenciando-se a incorporação e o acesso de grupos organizados da sociedade civil ao processo de decisão.

A bem da verdade, como Mettenheim (1999) destaca, a definição de poliarquia em Dahl (1971) traz embutida a referência ao policy process. Neste trabalho, Dahl indica as três condições necessárias para a existência de uma democracia, que podem ser resumidas na seguinte assertiva: os cidadãos devem ter garantida a oportunidade de formular e expressar preferências de políticas, as quais devem ser pesadas igualmente na conduta do governo. Em Preface to Democratic Theory, publicado em 1956, a referência ao processo decisório é bem mais explícita (ver Dahl, 1956:63 et passim). A forma de expressão das preferências dos cidadãos - pluralista - e o padrão decisório - o chamado muddling through - já haviam sido identificados por Dahl e Lindblom (1953) alguns anos antes da publicação do Preface. Essa dimensão da definição de democracia de Dahl, entretanto, é freqüentemente esquecida pela literatura especializada. Referência básica dessa literatura, a concepção de democracia de Dahl é quase sempre as- 
sociada às eleições e às condições necessárias para garantir que elas sejam regulares, livres e competitivas ${ }^{18}$.

Entre as condições vinculadas ao policy process e necessárias à existência de uma democracia, vale a pena destacar a oitava condição de Polyarchy, ligada à accountability vertical das burocracias, e esquecida pelo próprio Dahl. Esta condição requer que "instituições para formular políticas governamentais dependam de votos e de outras expressões de preferência" (Dahl, 1971:3, tradução livre).

A literatura sobre democratização, como indicado, refere-se exaustivamente às condições assinaladas por Dahl em seu trabalho mais citado, Polyarchy, para caracterizar as novas democracias. Textos mais recentes, contudo, têm se referido a Democracy and its Critics (1989) ${ }^{19}$, embora alguns trabalhos ainda se remetam à Polyarchy ${ }^{20}$. Democracy and its Critics aponta para os seguintes atributos definidores de poliarquias: (1) eleição dos governantes; (2) eleições livres e honestas; (3) sufrágio universal; (4) direito de candidatar-se a cargos; (5) liberdade de expressão; (6) fontes alternativas de informação; (7) liberdade de associação (idem:221). Cabe destacar que o oitavo atributo contido em Polyarchy, referente à dependência das instituições que formulam políticas governamentais em relação ao voto e outras expressões de preferência - ou seja, à accountability das burocracias -, desaparece nos livros mais recentes do autor, tanto no acima citado como em Dilemmas of Pluralist Democracy, de 1982. De fato, Dahl retira a oitava condição de Polyarchy e a embute, por assim dizer, na mesma primeira condição desses dois livros mais recentes, a saber: "o controle sobre decisões governamentais referentes à política pública está constitucionalmente investido em autoridades eleitas" (Dahl, 1982:10; 1989:221). Este ponto é de grande relevância para a discussão em pauta.

Com o aumento do tamanho da unidade democrática, que historicamente passa da cidade-estado ao Estado-nação, a participação e inclusão dos cidadãos cede lugar à representação, e a escolha de governantes passa a ser feita por meio da competição de elites por votos da população (Schumpeter, 1943). As autoridades eleitas têm significativa autonomia para formular e implementar políticas, prestando contas de sua performance durante as eleições. Ora, a oitava condição da Polyarchy abria a possibilidade de controle das instituições governamentais que formulam e implementam políticas, não apenas pelo voto, mas também "por outras expressões de preferência" dos cida-

\section{4}


dãos e, portanto, também em períodos entre eleições. Ao sumir, por assim dizer, com essa condição em seus trabalhos mais recentes, Dahl retira a possibilidade de controle democrático que não seja pelo voto, mesmo em períodos entre eleições ${ }^{21}$. Note-se que tampouco os estudiosos do tema discutiram ou se referiram ao sumiço da oitava condição de Polyarchy quando passaram a adotar a definição de democracia contida em Democracy and its Critics. O controle social das burocracias, na verdade, é questão muito pouco discutida na teoria democrática competitiva.

Ao incorporar, ou (re)incorporar, as características do processo de decisão na definição de democracia, como aqui proposto, reabre-se a possibilidade do controle vertical das burocracias, por meio de "outras expressões de preferências", e do acesso ao processo de decisão dos grupos organizados da sociedade, como propugna Malloy.

Vale observar que incluir a investigação dos mecanismos de decisão das políticas públicas e as formas de representação de interesses dos atores envolvidos para a caracterização dos novos regimes não significa postular acesso generalizado e pleno ao processo decisório. Não estou falando em democracia participativa (cf. Pateman, 1970) ou abandonando a teoria democrática competitiva. Tampouco estou menosprezando a importância de eleições regulares, livres e competitivas. Trata-se de, retendo o procedural mínimo em lugar central da definição de democracia, em vez de expandi-lo agregando-lhe novos atributos, adicionar a investigação do padrão decisório no período entre eleições como instrumento de análise para determinar os atributos do novo regime. Oimportante é destacar oqueéo novo regime e não o que deveria ser.

São várias as vantagens de se incorporar as características do processo de tomada de decisão na definição de democracia no período entre eleições:

(i) dá um caráter operacional, não normativo, à definição: quais as principais questões de política (policy)? quem participa? (por aqui é possível se detectar o controle de atores não eleitos sobre o processo decisório) quais seus recursos de poder e preferências de política? quais as mais importantes arenas de decisão? que tipos de mecanismos de decisão (pluralista, clientelista, corporatista, neocorporatista, informal) estão presentes no novo regime 


\section{Maria Helena de Castro Santos}

político e como convivem entre si? quais as formas de representação de interesses (permite o exame de outros mecanismos de agregação e intermediação de interesses diferentes de partidos políticos, foco das atenções do modelo liberal ocidental, tais como formas neocorporatistas, sempre polemizadas, ou redes sociais, forma cada vez mais importante no mundo globalizado)?

(ii) permite levar em conta características histórico-culturais e político-institucionais dos países em exame, expressas nas formas de representação de interesses e mecanismos de decisão;

(iii) permite examinar o caráter mais ou menos democrático dos regimes em construção no período entre eleições de forma mais abrangente (algumas das definições do procedural mínimo expandido incorporam condições específicas do processo de decisão, mas não examinam o processo como um todo);

(iv) permite discutir a questão do controle social das burocracias (ver acima);

(v) permite identificar vários tipos de democracia através das distintas combinações das características do processo decisório ${ }^{22}$.

A incorporação do processo decisório à definição de democracia não resolve, contudo, o problema da linha divisória entre regimes democráticos e não democráticos, já que ainda permanece por se decidir quais formas de representação de interesses, quais mecanismos de decisão e qual combinação dessas características autorizam a classificação dos novos regimes como democráticos.

Outro problema que se levanta é a impossibilidade de se selecionar uma amostra de países democráticos a priori, já que a definição sugerida é indutivamente construída. De fato, o caráter operacional dessa proposta conceitual se adequa melhor à investigação de um pequeno número de casos. A pergunta que orienta a pesquisa é, então: que tipo de regime está em construção? Neste caso, a questão metodológica não é a seleção de amostra, mas a cuidadosa seleção de casos (Collier, 1993).

Em resumo, o foco no processo de decisão permitirá tanto avaliar a capacidade do governo de resolver os problemas da sociedade e bem lidar com as pressões externas, quanto caracterizar os novos regimes

\section{6}


como mais ou menos democráticos, avaliando-os também nos períodos pós ou entre eleições.

A próxima seção analisará, a título de ilustração, o padrão de tomada de decisão no Brasil pós-autoritário.

\section{BRASIL: PADRÃO DUAL DE TOMADA DE DECISÃO}

Em trabalho anterior, baseado em evidências empíricas geradas por estudos de caso dos processos de decisão de políticas de ajuste selecionadas, durante o período Collor de Mello e Itamar Franco, aponto para o fato de que algumas políticas passam pelo Congresso e outras não:

“No caso das políticas de ajuste, parte passa pelo Congresso e parte não. A política cambial e grande número dos instrumentos de política monetária, essenciais na fase de estabilização, não passam, assim como também não passam as políticas de crédito e de comércio exterior. O Banco Central e as burocracias fazendárias produzem, em clausura relativa, sem controle social mais amplo, uma grande quantidade de instrumentos legais $[\ldots]^{23}$. A formulação da política industrial também tem passado ao largo do Congresso Nacional. Já as políticas de reforma estrutural (previdência, privatização, administrativa, tributária e fiscal) passam, necessariamente, pelo crivo do Legislativo, até porque dependem, em grande medida, de reforma da Constituição" (Castro Santos, 1997:359).

Este fato sugere que, no Brasil pós-autoritário, o processo de tomada de decisão ocorre em duas arenas de poder paralelas: uma representativa e outra burocrática, caracterizando um padrão dual do processo decisório, em que estas arenas coexistem em permanente tensão ${ }^{24}$.

Arena Representativa - caracterizada pela política pluralista, a arena representativa gravita em torno do Congresso, seu locus de decisão principal. No caso do Brasil, ela é fortemente permeada pela política clientelista. Seu padrão de decisão é bastante complexo e não se restringe de forma alguma às regras constitucionais e regimentais do Parlamento. Varia com o tipo de política em questão (cf. Lowi, 1964; e Castro Santos, 1997, para a adaptação de Lowi a este caso), podendo ser caracterizado através da análise das relações Executivo-Legislativo. Quanto maior o número de interesses em jogo, maior a complexidade do padrão de decisão e maiores as chances de parali- 
sia decisória. Os padrões mais complexos (por exemplo, as reformas da previdência social, fiscal e tributária) envolvem um grande número de atores, tais como os ocupantes dos altos escalões das burocracias envolvidas na política em questão, o próprio presidente e sua assessoria direta, os negociadores do governo junto ao Congresso, os partidos políticos e seus líderes, o Colégio de Líderes, os líderes do governo no Congresso, os grupos de interesse afetados (empresários e suas associações de interesse, sindicatos de trabalhadores, associações de aposentados etc.), os governadores de estado, os prefeitos e, algumas vezes, o próprio Judiciário. Estes atores interagem por intermédio de canais diversificados de comunicação e variados mecanismos de decisão, configurando padrões complexamente elaborados, embora não formalmente institucionalizados (cf. O'Donnell, 1996b e, para uma descrição detalhada desses padrões informais para o caso brasileiro, ver Castro Santos, 1997).

Por outro lado, partidos políticos pouco institucionalizados, marcados pela tradição intervencionista do Estado e pelo caráter elitista e artificial de sua formação (com a exceção recente do PT e de alguns partidos de esquerda), são submetidos a certas regras eleitorais, tais como ausência de fidelidade partidária, personalização dos mandatos, facilidade tanto de troca de partido como de constituição de novos. Partidos dessa natureza exibem o que chamei de comportamento segmentado (Castro Santos, 1997), isto é, ocupando distintas posições no espectro ideológico negociam com o Executivo segundo diferentes moedas. Assim, a moeda de troca clientelista (cf. Hagopian, 1992; 1996) está fortemente presente em partidos pertencentes ao centro e à direita do espectro ideológico. Os partidos de esquerda, por sua vez, mostram-se menos abertos a negociações, já que são mais principalistas, enquanto parte dos partidos do centro do espectro ideológico negocia de forma mais propriamente pluralista, isto é, em torno de questões de política. De maneira geral, o comportamento dos partidos é ainda marcado por constrangimentos eleitorais, especialmente fortes em anos de eleições. Por fim, interesses suprapartidários rompem as fronteiras dos partidos, dividindo-os em segmentos distintos. O resultado é, em conseqüência, um sistema multipartidário, polarizado e altamente fragmentado.

A institucionalização informal dos mecanismos de interação entre os atores e suas formas de representação de interesses, associada às características descritas acima dos sistemas eleitoral e partidário e do 
comportamento parlamentar dos partidos, gera duas importantes conseqüências para a arena representativa. Por um lado, essa associação de variáveis ressalta a importância para a tomada de decisão na arena representativa dos atributos pessoais das lideranças do governo e da oposição, e mesmo da equipe econômica, das variáveis conjunturais e dos mecanismos e procedimentos informais. Por outro, essa combinação de características dificulta a construção de coalizões de sustentação do governo, obrigando o Executivo a empenhar-se na obtenção de maiorias a cada votação. Dessa forma, freqüentemente, árduas negociações entre o Executivo e o Congresso prolongam o tempo da tomada de decisões, quando não geram paralisia decisória. As conseqüências desse padrão de relação Executivo-Legislativo para a capacidade governativa do Estado são, portanto, significativas ${ }^{25}$.

Por fim, observa-se que, de modo geral, todo ator social com recursos organizacionais fortes o suficiente para engajar-se em ações coletivas consegue participar do processo de decisão dessa arena. Contudo, a baixa institucionalização formal dos mecanismos de decisão das políticas submetidas ao Congresso e a forte presença de modos clientelistas e informais de representação de interesses afastam essa arena da prática da política democrática.

Arena Burocrática - a decisão é tomada dentro do aparelho de Estado, isto é, no âmbito do Executivo de maneira geral e, em particular, das agências burocráticas a cargo da política ou partes da política em questão. Ainda que informal, o acesso a essa arena de atores sociais excluídos pelo regime militar, com destaque para representações dos trabalhadores, é das poucas diferenças que se registram com relação ao regime precedente. Há aí, portanto, um insulamento relativo no que se refere aos interesses econômicos, políticos e sociais ${ }^{26}$. Relações informais entre atores estratégicos e os tomadores de decisão são freqüentes e dominantes, embora se conte, em alguns casos, com alguns mecanismos institucionalizados de decisão, tais como câmaras, conselhos e comissões relativas a políticas setoriais. Esta arena, em resumo, apresenta accountability reduzida, tanto vertical (com relação à sociedade em períodos entre eleições), como horizontal ${ }^{27}$.

Ao contrário do período autoritário ${ }^{28}$, não há no Brasil evidência empírica sistemática sobre a arena burocrática no período de democratização, registrando-se, em vez disso, esparsos estudos de caso ${ }^{29}$. Meu 
próprio trabalho (Castro Santos, 1993) refere-se ao processo de decisão no período autoritário, focalizando a política do álcool combustível - política estratégica no mundo pré-globalizado e pós-choques de petróleo. Esse estudo de caso mostra um complexo padrão de decisão que combina uma estrutura fragmentada e alto conflito interburocrático (três centros de decisão e um número impressionante de agências burocráticas envolvidas), mecanismos segmentados de decisão (atores sociais dirigindo-se a diferentes agências burocráticas de acordo com a questão em foco) e um sistema de representação de interesses que elimina os grupos desprivilegiados e se abre complexamente ao grande capital através de representações coletivas (associações corporativas "oficiais" e paralelas) e individualizadas, formais, informais e institucionais-informais (agências atuando como brokers de interesses privados junto a outras instâncias burocráticas), além de anéis burocráticos. A forma prevalecente de representação de interesses é, contudo, a informal. Há, então, uma afinidade eletiva entre informalidade, estrutura de decisão fragmentada e mecanismos segmentados de decisão, que caracteriza o autoritarismo do Brasil pós-64 e o distancia do corporatismo, associado pela literatura com o Estado burocrático-autoritário (cf. O’Donnell, 1977; 1979; Collier, 1979; Malloy, 1977), do qual o Brasil é considerado o arquétipo.

A tarefa aqui é examinar, então, até que ponto a arena burocrática, única existente no regime burocrático-autoritário anterior, sofreu mudanças no período de democratização. Minha hipótese é que não ocorreram mudanças profundas nessa arena com a democratização, à exceção da mencionada incorporação de atores estratégicos anteriormente excluídos.

No Brasil, líderes das três centrais sindicais passaram a ser informalmente auscultados, como no caso das reformas da previdência e administrativa no governo Cardoso. Contudo, a maior ou menor inclusão dos atores sociais na arena burocrática oscilou ao longo dos governos democráticos. Assim, na primeira fase do governo Collor de Mello, registra-se um movimento deliberado de abolir ou reestruturar mecanismos institucionalizados de decisão com a participação de atores sociais. Tal é o caso do Conselho de Desenvolvimento Industrial - CDI, do Conselho Monetário Nacional - CMN, do Conselho de Comércio Exterior - CONCEX e da Comissão de Política Aduaneira - CPA. Entre maio de 1991 e setembro de 1992, porém, observa-se 
Que Democracia? Uma Visão Conceitual desde a Perspectiva dos Países...

a tentativa de retorno ao padrão de relações entre atores públicos e privados vigente até o governo Sarney. De fato, pretendeu-se construir um conjunto de fóruns de negociação com a presença de empresários e, algumas vezes, de trabalhadores, voltado para a formulação e implementação da política de competitividade industrial. Foram recriadas, nesse sentido, as câmaras setoriais (em estilo neocorporatista). A articulação desses fóruns, entretanto, nunca se materializou e o padrão de relações entre o setor público e o privado em que essas se baseavam foi abolido com a chegada de Fernando Henrique Cardoso ao cargo de ministro da Fazenda no governo Itamar Franco. A experiência das câmaras setoriais foi, nessa ocasião, mais uma vez aborta$\mathrm{da}^{30}$. Esse padrão de relações entre as burocracias e os atores sociais continuaria durante as duas administrações de Cardoso, o que apontaria para o maior insulamento da burocracia em relação aos interesses políticos e econômicos. Em direção oposta, contudo, cita-se a promulgação da lei no 9.790/99, que dispõe sobre a qualificação, no universo do terceiro setor, daquelas organizações da sociedade civil que atuam na produção de bens públicos como Organizações da Sociedade Civil e de Interesse Público - OSCIPs. A participação dessas Organizações é garantida e legalizada mediante a assinatura de termos de parceria com o Estado. As OSCIPs devem contemplar as áreas de saúde, educação, assistência social, defesa dos direitos de grupos específicos da população, trabalho voluntário, proteção do meio ambiente, concessão de microcrédito e outras. Ainda em estágio inicial, essa estrutura de relacionamento entre as burocracias e a sociedade civil permanece por se consolidar. Parece se vislumbrar, entretanto, nas administrações Cardoso, um padrão bifurcado de relacionamento com os atores sociais. Ou seja, por um lado, aponta-se para um padrão de insulamento das burocracias encarregadas da política econômica em relação às chamadas forças produtivas (empresários e trabalhadores), cujos interesses são auscultados de maneira predominantemente informal. Por outro, no que se refere às políticas sociais e de meio ambiente, a tendência é construir-se estruturas de decisão, com a participação institucionalizada dos grupos afetados por essas políticas.

No novo ambiente democrático brasileiro, a prestação de contas horizontal da arena burocrática permanece reduzida ${ }^{31}$. Cita-se, contudo, como instâncias de controle horizontal bastante ativas, o Tribunal de Contas da União - TCU, órgão do Legislativo que supervisiona as 
ações do Executivo, e o Controle Interno da Secretaria do Tesouro Nacional - CISET, órgão do Poder Executivo que fiscaliza as contas e gastos das outras agências burocráticas. Também o mecanismo de decisão segmentado, característico do período autoritário, parece continuar funcionando, incluindo agora a arena representativa. Isto é, os atores sociais dirigem-se tanto às agências burocráticas encarregadas da política de seu interesse como aos partidos políticos, dependendo da questão em jogo ou da fase do processo de decisão dessa política.

O Brasil, por outro lado, pode ser visto como uma democracia delegativa, segundo o modelo de O'Donnell (1996a; 1996b), em contraposição às democracias representativas mais antigas. A concepção de democracia delegativa é de grande utilidade conceitual para a análise do processo de consolidação democrática de países em desenvolvimento. Na verdade, existe grande afinidade eletiva entre um padrão dual de decisão, como o indicado acima para o caso brasileiro, e o modelo de democracia delegativa. Minha proposta, portanto, é investigar tanto este como outros tipos de novos regimes, e sua capacidade governativa, através da análise e caracterização dos processos decisórios que se estruturam nos países que passam por processos de transição política e econômica.

A partir desta proposta, indico, nas conclusões, algumas questões relevantes referentes à capacidade governativa dos países em transição democrática, e discuto, do ponto de vista conceitual, a adequação do modelo de democracia liberal ocidental para a análise dos novos regimes políticos que se estruturam nesses países.

\section{CONCLUSÕES: DEMOCRACIAS “DIMINUIIDAS” OU REGIMES HÍBRIDOS? CONSIDERAÇÕES CONCEITUAIS}

Se é razoável supor que o padrão de tomada de decisão dos países que passam por processos de transição apresenta características semelhantes às descritas acima para o caso brasileiro, proponho que se analise esses processos a partir das formulações (hipóteses de trabalho) que se seguem.

Sob a pressão da liberalização econômica e o desafio da democratização, o processo de mudança de regime em países emergentes, qualquer que seja a seqüência das transições econômica e política, e qualquer que seja a forma de transição democrática (por ruptura, pactada 
ou por extrication), provavelmente evolverá em torno de um padrão dual de decisão, com características comuns ao padrão descrito para o caso brasileiro. Se o caráter dual é comum ao padrão de tomada de decisão dos países em desenvolvimento, ele apresenta, contudo, características específicas derivadas dos distintos legados histórico-culturais e político-institucionais desses países, bem como dos variados desenhos institucionais dos novos regimes. Essas características, combinadas, influenciarão de forma distinta as possibilidades de consolidação democrática. Não se espera que a arena burocrática desses países, provavelmente único locus de decisão de parte significativa das medidas que compõem as políticas de estabilização e abertura comercial, apresente modificações profundas nas formas de tomada de decisão com relação ao regime autoritário precedente, exceto pela incorporação de atores estratégicos anteriormente excluídos. A accountability dessa arena, tanto vertical quanto horizontal, provavelmente, permanecerá reduzida no período pós-autoritário, embora não se possa menosprezar o importante papel de controle da mídia, responsável pelo significativo aumento de transparência dessa arena. A arena representativa, centrada no Congresso, pelas especificidades inerentes a cada país, com destaque para os sistemas partidário e eleitoral adotados, as formas de governo (presidencialista ou parlamentarista) e os vínculos partidários com elites tradicionais, deverá apresentar graus variados de dificuldades para a formação de coalizões estáveis de suporte governamental e, portanto, probabilidades distintas de paralisia decisória. O Executivo será o poder predominante, de modo geral, mas o caráter delegativo do regime deverá apresentar variações conforme o desenho institucional dos novos regimes e de seus legados histórico-culturais e político-institucionais. Da mesma forma, o Congresso, condicionado por essas variáveis, apesar de apresentar baixa capacidade política e técnica para propor projetos de política alternativos aos do Executivo, terá papel mais ou menos cooperativo, ou mais ou menos conflitivo com este poder, dependendo das características da coalizão de suporte governamental e do arranjo institucional dos novos regimes, da questão de política em pauta, das circunstâncias e variáveis conjunturais, e mesmo dos atributos pessoais das lideranças partidárias.

Essa combinação de estilos de decisão e formas de representação de interesses coloca problemas cruciais para a criação de capacidade governativa em contexto democrático, na medida em que suscita ques- 


\section{Maria Helena de Castro Santos}

tões, tais como: como aumentar ou melhorar a representação vis-à-vis a delegação no novo regime? como aumentar e institucionalizar os checks and balances entre o Executivo e o Legislativo, sem esquecer o Judiciário, que até agora não está sujeito a nenhum tipo de controle? como diminuir a representação informal de interesses e a patronagem nas arenas de decisão? como aumentar a accountability horizontal? deve-se aumentar o controle vertical da arena burocrática ${ }^{32}$ ? ou deve a arena burocrática insular-se da política pluralista, que deverá concentrar-se apenas no Parlamento, como propugnado por parte da literatura de reforma econômica? e se o Parlamento, como no caso do Brasil, apresentar características que inibem a política pluralista democrática? como diminuir a probabilidade de paralisia decisória no Congresso e aumentar as possibilidades de construção de maiorias estáveis de sustentação ao governo? ${ }^{33}$ como melhorar a comunicação entre as duas arenas, especialmente em situações emergenciais? $?^{34}$

Este conjunto de questões nos leva de volta a indagações de caráter normativo e conceitual sobre o tipo de democracia que os países em transição serão capazes de construir. É possível consolidar nesses países uma democracia do tipo liberal ocidental? Esses países estarão condenados a consolidar um "tipo diminuído" (diminished type) de democracia, conforme a expressão usada por Collier e Levitsky ${ }^{35}$, ou estarão caminhando para regimes híbridos, que combinarão elementos de regimes autoritários e democráticos, e dessa forma se consolidarão?

O processo dual de decisão acima descrito, e que provavelmente caracteriza os regimes pós-autoritários de modo geral, mostra uma forte afinidade eletiva com formas híbridas. Entretanto, trabalhar com o conceito de regime híbrido é uma questão de forte sensibilidade do ponto de vista normativo. Como visto anteriormente, embora parte relevante da literatura de democratização assuma uma postura crítica quanto ao modelo ideal de democracia à moda dos países industrializados ocidentais, e vários scholars desse veio da literatura trabalhem com a concepção de regimes híbridos, poucos utilizam explicitamente esse rótulo. Malloy (1993) e Karl (1995) foram as exceções citadas. Regimes híbridos combinam, na formulação de Malloy, eleições institucionalizadas e práticas autoritárias, ou, na expressão de Karl, indicam uma aquisição desigual dos requisitos procedurais de democracia. O'Donnell, por exemplo, cuja "democracia delegativa" aponta na direção de regimes híbridos, embora chegue a se referir a

\section{4}


um novo animal ${ }^{36}$, em comparação com as democracias representativas mais antigas, considera-a, no entanto, como um tipo de democracia. Munck (1996), em uma complexa formulação conceitual de mudança de regime, refere-se à "hibridização". Collier, entretanto, considera regimes híbridos como "tipos diminuídos" de democracia, dos quais a democracia delegativa é um exemplo ${ }^{37}$.

Na verdade, um novo tipo de regime, com um padrão dual de decisão, que combina o procedural mínimo de Schumpeter/Dahl com práticas autoritárias, pode tanto ser considerado um tipo diminuído de democracia como um regime híbrido. Um regime híbrido, por sua vez, pode ser transitório, em direção a um regime plenamente democrático $^{38}$, ou não transitório, consolidando-se como tal. O mesmo vale para tipos diminuídos de democracia. Então, qual a diferença entre esses dois rótulos?

A discussão em torno desse tema não é apenas de natureza semântica e está longe de estar encerrada. É uma questão importante cuja discussão, a meu ver, se dá em dois níveis básicos. O primeiro deles toca profundamente o viés normativo pró-democracia impregnado no pensamento e ações das elites, da academia e dos cidadãos dos países desenvolvidos ocidentais, e que tem se incorporado e espalhado pelo resto do mundo. Considerado, em geral, o mais imperfeito e ao mesmo tempo o melhor regime político de todos os tempos, o único capaz de proporcionar ao homem as melhores condições de vida e a dignidade plena, a promoção do regime democrático é vista como missão a ser levada aos países em desenvolvimento, os quais, em geral, não só a aceitam como não abrem mão dessa meta. Mesmo as formulações acadêmicas mais críticas quanto à possibilidade de construção do modelo liberal ocidental nos países que passam por mudança de regime mantêm, de modo geral, a crença na validade universal desse modelo ideal de democracia. A discussão aqui, portanto, quanto ao caráter e ao rótulo dos novos regimes, é de natureza normativa, moral e filosófica.

Em um segundo nível de discussão, contudo, mesmo que as preferências normativas dos tomadores de decisão e cidadãos politicamente participantes dos países em desenvolvimento sejam majoritariamente pró-democracia, o modelo liberal representativo de democracia deve também ser encarado como expressão de hegemonia e forma de pressão externa da potência dominante no mundo pós-Guerra Fria. A 
exportação da democracia tem sido exercida de várias maneiras: por meio da política externa americana, com destaque para a política de ajuda, de radiodifusão, de programas internacionais de intercâmbio de estudantes e de acadêmicos; por meio da atuação da ONU, da OEA, de organizações não-governamentais, do National Endowment for Democracy; por meio de intervenções militares e da condicionalidade política. Esta última tem sido uma exigência cada vez maior para a concessão de ajuda externa econômica por parte das instituições financeiras multilaterais, como o Banco Mundial e o FMI, que se valem das medidas anuais dos regimes políticos do mundo pela Freedom House ${ }^{39}$. O modelo de democracia imposto é o gerado pelos valores das sociedades americana e européias ocidentais, embutidos nas formulações acadêmicas do conceito de democracia liberal, seguindo o veio Schumpeter/Dahl. Neste segundo nível de análise, portanto, as diferentes características e os rótulos atribuídos aos novos regimes têm conseqüências práticas, na medida mesma em que provocarão distintas reações dos países hegemônicos, especialmente os Estados Unidos, no que se refere às formas de pressão internacional para a exportação de democracia.

É, portanto, muito difícil deixar cair o rótulo democrático. Proponho, não obstante, considerarmos os novos regimes, com padrões duais de decisão - sejam eles tomados como regimes híbridos ou tipos diminuídos de democracia -, em seus próprios termos, isto é, com seus legados histórico-culturais e político-institucionais específicos e, a partir daí, então, passarmos a questionar o que pode ser feito para melhorar seus aspectos representativos em detrimento do caráter delegativo que os têm distinguido. Pode-se investigar, neste caso, outras formas de representação de interesses que não partidos políticos (cf. a este respeito Schmitter, 1992; Schmitter e Karl, s/d), foco primordial do modelo liberal pluralista, em geral considerados a única forma legítima de representação democrática de interesses. No contexto dos países em desenvolvimento, contudo, especialmente nos de estrutura socioeconômica acentuadamente desigual, essas outras formas (como, por exemplo, formas neocorporativas) de representação de interesses podem abrir o acesso ao processo decisório a grupos sociais sem capacidade de se fazer representar adequadamente na esfera da política pluralista. Ou, ainda, pode-se analisar formas de melhorar o alcance universal do Estado de direito (rule of law) e das instituições 
jurídicas, diminuindo-se o particularismo da vida política e social das nações em processo de mudança de regime.

A exigência junto aos países em desenvolvimento de referência absoluta ao "modelo ideal" de democracia liberal ocidental - exigência esta que as próprias democracias ocidentais mais antigas têm dificuldade de atender ${ }^{40}$ — gera a tendência de se concentrar a atenção na arena representativa dos novos regimes e no seu aperfeiçoamento, negligenciando-se suas características autoritárias resilientes, na medida mesma em que estas são consideradas transitórias. Procedendo como sugerido, contudo, as chances de consolidação de regimes de caráter híbrido diminuirão em favor de um novo tipo mais democrático, melhor dizendo, um tipo híbrido em que os componentes democráticos terminem por predominar sobre as características autoritárias.

Esses novos regimes, produtos de contextos histórico-culturais e político-institucionais diversos dos das democracias liberais ocidentais, poderão vir a se constituir em um "novo animal", deixando de ser considerados "menos" que outros, ou tipos "diminuídos" de democracia $^{41}$. Mesmo que não se qualifiquem como democracias plenas, segundo o modelo liberal ocidental hegemônico, esses regimes certamente serão, do ponto de vista normativo, muito melhores do que os regimes autoritários precedentes ${ }^{42}$.

Sugiro, em resumo, como referência conceitual para a caracterização dos regimes pós-autoritários como mais ou menos democráticos, que se acrescente ao procedural mínimo de democracia, conforme utilizado pela literatura de democratização, as características do seu processo de decisão (formas de representação de interesses, mecanismos de decisão e acesso à decisão). Esse procedimento é particularmente relevante para caracterizar os novos regimes nos períodos entre eleições. Procedendo como proposto, estaremos criando a possibilidade de um olhar sobre os novos regimes da perspectiva dos países em desenvolvimento, pouco importando o rótulo que venham a receber. $\mathrm{O}$ caminho, contudo, em direção a mais democracia, estará sempre aberto. 


\section{Maria Helena de Castro Santos}

\section{NOTAS}

1. A primeira e longa onda de democratização na história do mundo moderno começou a partir dos anos 20 do século XIX, com o aumento significativo da proporção da população masculina com direito a voto nos Estados Unidos. Esse movimento se prolongou por quase um século, até 1926, quando os sistemas políticos existentes, gradualmente, desenvolveram instituições democráticas. A reversão da primeira onda ocorreu basicamente nos países que adotaram formas democráticas de governo após a Primeira Grande Guerra, tomando-se como ponto inicial a Marcha sobre Roma de Mussolini em 1922. A segunda onda de democratização é curta, começando após a Segunda Grande Guerra com a vitória dos aliados e o início do final da era da colonização ocidental. A reversão da segunda onda a partir dos anos 60, com a América Latina à frente, onde golpes militares inauguram longos períodos de autoritarismo, traz consigo acentuado pessimismo quanto à possibilidade de regimes democráticos em países em desenvolvimento. Schmitter e Santiso (1997) consideram a existência de quatro ondas de democracia, já que a primeira lhes parece longa demais. Assim, a primeira onda está limitada ao período 1848-1852; a outra acompanha a Primeira Guerra Mundial, entre 1914 e 1922; a terceira, ocorre logo após a Segunda Guerra, continuando até o colapso de democracias pós-coloniais na África e Ásia (1945-meados de 1960). Segundo esses autores, portanto, estaríamos na quarta onda de democratização.

2. A partir da definição procedural de democracia, segundo a perspectiva de Schumpeter/Dahl, a Freedom House considera democráticos países cujos governos e representantes legislativos foram eleitos em processos políticos de uma maneira geral justos e livres. Organização não lucrativa, criada em 1950 e baseada em Nova Iorque, a Freedom House adverte para o fato de que liberdade e democracia não são sinônimos uma da outra, apesar da estreita correlação que guardam entre si. A partir dos indicadores de liberdade - "liberdades civis" e "direitos políticos" —, essa organização procede anualmente ao Comparative Survey of Freedom, classificando os países do mundo segundo três categorias: livres, parcialmente livres e não livres. Em 1999, dos países formalmente democráticos, 85 foram classificados como livres e 60 como parcialmente livres.

3. Para Jowitt, "Um novo modo de vida consiste em uma nova ideologia que ativamente rejeita as instituições sociais, econômicas, religiosas, administrativas, políticas e culturais existentes" (1996:30, tradução livre).

4. Jowitt adverte, contudo, que a única exceção possível seria o islamismo fundamentalista. Este texto já estava redigido quando dos acontecimentos de 11 de setembro em Nova Iorque. Note-se a acuidade das previsões do autor ao identificar o islamismo fundamentalista como o único possível "modo de vida" surgido no Terceiro Mundo capaz de desafiar e se contrapor à civilização democrática liberal e capitalista.

5. Note-se que o terrorismo fundamentalista, além do mais, pode ser identificado com o que Jowitt chamou de "movimentos de cólera".

6. Esta assertiva foi reavaliada após a chamada crise asiática de 1997.

7. Lipset (1996) faz essa observação, acrescentando, contudo, que não há evidência de que os esforços dos que se preocupam em aumentar as possibilidades de governos 


\section{Que Democracia? Uma Visão Conceitual desde a Perspectiva dos Países...}

democráticos estáveis via o desenho de instituições políticas sejam recompensados.

8. No início da década de 90, o Journal of Democracy publicou vivo debate sobre essas questões envolvendo Linz, Horowitz, Lipset, Lijphart, Lardeyet e Quade. Os artigos estão compilados em Diamond e Plattner (1996b).

9. Ver o já clássico artigo de Robert Putnam (1995), “Bowling Alone: America's Declining Social Capital".

10. O National Endowment for Democracy, organização privada não lucrativa, recebe anualmente recursos do orçamento federal americano para o desenvolvimento de programas destinados ao fortalecimento das instituições democráticas no mundo. A organização financia o Journal of Democracy, criado em 1991, que se tornou importante periódico acadêmico internacional sobre democracia. Faz agora parte do International Forum for Democratic Studies, criado em 1994, como o braço de pesquisa e informação do National Endowment for Democracy.

11. Desde 1960, quando Seymour Lipset publicou seu clássico Political Man, ficou bem estabelecida a associação positiva entre nível de desenvolvimento econômico e política democrática. Huntington considera que poucas relações entre fenômenos sociais, econômicos e políticos são mais fortes do que esta. Os trabalhos de Przeworski e seus associados (Alvarez et alii, 1996; Przeworski et alii, 1996; Przeworski e Limongi, 1997) qualificam esta assertiva. Para uma análise do "estado das artes" nesta questão, ver Rowen (1996).

12. Esses autores identificam o trabalho de O'Donnell e Schmitter (1986), Tentative Conclusions about Uncertain Democracies, como o turning point neo-institucionalista deste veio da literatura.

13. Tomando como referência empírica a América Latina, Naím (1995) aponta para um padrão emergente onde as duas fases do processo de reforma se sobrepõem.

14. Na verdade, Huntington, em seu Political Order in Changing Societies (1968), questiona o viés normativo pró-democrático da teoria da modernização que se desenvolve nos Estados Unidos a partir da década de 50. Em documento preparado para a Wingspread Conference, 17-18 de abril de 1974, ele diz textualmente: "sem contar com os aspectos inumanos e iliberais de seu sistema político autoritário, o modelo tecnocrático brasileiro é congruente com os interesses americanos" (:22, tradução livre). Para uma melhor elaboração deste ponto, inclusive para a diferenciação entre a orientação democrática da teoria da modernização e a da atual literatura de democratização, ver Castro Santos (1997).

15. A bem da verdade, esta não é uma questão completamente resolvida na literatura de reforma econômica, embora já haja consenso de que se a fase de estabilização pode prescindir de um processo de decisão democrático, a fase de reformas estruturais só será bem-sucedida se negociada democraticamente (ver, acima, a seção "Democracia e Reforma Econômica").

16. O recurso ao chamado procedural mínimo expandido é uma das estratégias apontadas por Collier e Levitsky (1997) para a inovação conceitual, ao mesmo tempo que evita o "esticamento conceitual" (conceptual stretching).

17. Em trabalho mais recente, $\mathrm{O}^{\prime}$ Donnell (1997b) focaliza, especificamente, as questões da rule of law e da extensão da cidadania sob a universalidade do direito como um 


\section{Maria Helena de Castro Santos}

atributo da democracia tão central quanto as características (poliárquicas) do regime político. Ele não chega, contudo, explicitamente, a adicionar este atributo à definição procedural mínima de democracia nem a definir aí, a cut-offline entre democracias e não-democracias.

18. Além de Karl (1986), que pioneiramente chama a atenção para a falácia das democracias eleitorais, Diamond (1996c) enfatiza a excessiva atenção que a literatura de democratização coloca no processo eleitoral. Diferenciando democracia eleitoral de democracia liberal, este autor conclama os colegas a serem mais exigentes na definição de democracia, e reforça a importância do papel dos Estados Unidos para a construção da democracia liberal nos novos regimes, por meio das atividades de entidades como a Freedom House e o National Endowment for Democracy (ver, também, Diamond, 1999).

19. Este é o caso de O’Donnell, cujos primeiros trabalhos sobre o tema (p. ex., O'Donnell, 1992; 1996a) referiam-se à Polyarchy, enquanto os mais recentes (p. ex., 1996b; 1997a; 1997c) passaram a basear-se em Democracy and its Critics.

20. Por exemplo, em Patterns of Democracy (1999), Lijphart não só usa as condições contidas em Polyarchy, como acredita que esses requisitos já estão implícitos na definição de democracia de Lincoln, segundo a qual o governo deve ser pelo povo e para o povo.

21. Note-se, contudo, que nas reflexões iniciais de Dahl sobre democracia, expressas em 1956 em Preface to Democratic Theory, o autor refere-se explicitamente ao período entre eleições. Na verdade, ele divide o policy process em quatro períodos: eleitoral, pré-eleitoral, pós-eleitoral e entre eleições. Este último requer, para que se atinja o máximo de igualdade política e soberania popular, as seguintes condições: “[...] que todas as decisões no período entre eleições sejam subordinadas ou executadas por aqueles que chegaram [ao poder] durante a fase das eleições, isto é, as eleições estão, em um certo sentido, controlando; ou que as novas decisões durante a fase entre eleições sejam governadas pelas sete condições precedentes, operando, entretanto, sob circunstâncias institucionais bastante diferentes; ou [que] ambos os casos [ocorram]" (:71, tradução livre). Esta periodização do processo decisório, contudo, não seria retomada nos trabalhos futuros do autor.

22. No mesmo caminho, como indicado na segunda seção deste trabalho, Schmitter e Karl (1996) sugerem a possibilidade de combinações distintas de componentes democráticos, caracterizando sistemas políticos diferentemente democráticos.

23. Note-se que nos Estados Unidos, protótipo da democracia consolidada, também ocorre o insulamento do Banco Central e de outras burocracias ligadas à política econômica. A accountability vertical das burocracias é, portanto, problema universal da teoria democrática empírica, remetendo-nos diretamente à discussão do sumiço da oitava condição de Dahl, referida acima.

24. Schmitter (1992), com alguma semelhança ao proposto aqui, sugere uma conceituação de democracia política não como regime, mas um composto de regimes (partial regimes), cada um deles institucionalizado em torno de distintos loci para a representação de grupos sociais e a resolução de seus conflitos. Partidos políticos, associações, movimentos sociais, localidades e várias clientelas competiriam e coalesceriam através desses diferentes canais na tentativa de capturar postos políticos e influenciar as políticas públicas. Os diferentes tipos de democracia combinariam 


\section{Que Democracia? Uma Visão Conceitual desde a Perspectiva dos Países...}

de formas distintas os regimes parciais. São quatro os regimes parciais identificados por Schmitter: o constitucional, o de representação, o clientelista e o de concertação. Em trabalho recente não publicado, Schmitter retoma o tema, indo mais além para sugerir que, no contexto de consolidação da democracia, os regimes parciais tendem a crescer em número, sendo que muitos ficarão constitucionalmente indefinidos, "pois é precisamente nos interstícios entre tipos diferentes de representações que as normas constitucionais são mais vagas e menos prescritivas" (tradução livre). O autor sugere, contudo, que a natureza das relações civis-militares seja explicitamente incorporada ao núcleo central dos regimes parciais (Schmitter e Karl, s/d, cap. 5). Com relação à proposta que faço aqui, seria o caso de se investigar quais regimes parciais se entrecruzariam nas arenas burocrática e representativa (Congresso), as quais teriam uma dimensão, por assim dizer, espacial.

25. Mas confira a literatura sobre governo dividido, a qual, analisando a experiência americana, enfatiza a funcionalidade de governos divididos e separados para a capacidade governativa desses governos, argumentando que a difusão de poder abre maior espaço para a negociação entre os poderes constituídos e, portanto, para um maior controle do Executivo. Ao contrário do que se pode pensar, continua a argumentação dessa literatura, governos minoritários apresentam capacidade governativa no mínimo tão boa quanto governos majoritários. Para uma referência a essa literatura e sua aplicação ao caso do Brasil, cf. Mettenheim (1999).

26. Mesmo o Banco Central, que, dentre as agências burocráticas, seria a mais impermeável de todas à política, poderia ser enquadrado nesse caso (cf. Rua, 1997).

27. Trata-se aqui da questão da reestruturação da função de controle entre agências governamentais e, mais especificamente, da criação ou reformulação de agências de controle entre os poderes constituídos. Para uma análise minuciosa da horizontal accountability, ver O’ Donnell (1997a) e para uma definição detalhada desse atributo democrático, ver idem: esp. 18-19.

28. Cf. Paixão e Castro Santos (1988) para uma análise dos diversos tipos de estudo sobre o processo decisório do Estado burocrático-autoritário no Brasil.

29. Cf., no período de democratização, os importantes estudos de caso sobre a política de estabilização econômica e de abertura comercial (Pio, 1997; 2001) e sobre a política industrial (Rua e Aguiar, 1995; Diniz, 1997).

30. Ver a esse respeito a detalhada e competente análise de Diniz (1997, esp. cap. $4-$ "Câmaras Setoriais e Governança Econômica").

31. Os trabalhos de Pio (2001) e Rua e Aguiar (1995) confirmam isto.

32. Coloca-se aqui a discussão da criação de formas neocorporatistas de representação de interesses, apropriadas para a arena burocrática, onde o processo de decisão é setorial. A argumentação contrária a essas formas de representação de interesses enfatiza a reprodução, nas arenas neocorporativas de decisão, da desigualdade da capacidade de representação coletiva dos atores chamados a participar dessas arenas, o que seria antidemocrático. A argumentação a favor do modelo neocorporativo é que, mesmo que de forma desigual, grupos com menor capacidade de ação coletiva teriam seus interesses representados nessas câmaras corporativas, o que certamente é mais democrático do que não tê-los representados nas decisões que os afetam. O governo, no exercício do poder moderador, pode sempre tentar diminuir essas desigualdades e, imbuído do espírito público, procurar reforçar o interesse republicano 


\section{Maria Helena de Castro Santos}

em contraposição aos interesses privados ali representados. A tarefa não é fácil e há sempre o risco de o governo ser colocado na "cadeira do dragão", tornando-se refém de interesses privados poderosos. Há, contudo, a possibilidade de diminuir esse risco através de redesenhos institucionais. A respeito deste tema, vale a pena referir-se a Schmitter (1992), onde o autor analisa e avalia (positivamente) a importância de formas neocorporativas de representação de interesses (e outras formas diferentes de partidos políticos) na consolidação das novas democracias.

33. Aqui a ênfase da literatura é geralmente posta na reforma dos sistemas eleitoral e partidário dos países emergentes em transição. A questão dos legados autoritários, contudo, é também fundamental. Legados como os da política tradicional, baseada em patronagem, explicam, em grande medida, o fraco comprometimento partidário das elites tradicionais, que assim se espalham pela maioria dos partidos políticos, imprimindo aí seu estilo antidemocrático de fazer política (os trabalhos citados de Frances Hagopian sobre este tema são fundamentais). Esses legados tradicionais são, portanto, em grande medida, responsáveis pelas dificuldades de construção de maiorias estáveis de apoio ao governo no Congresso e, portanto, pela forte probabilidade de paralisia decisória nessa arena. Deve-se ter em mente, desse modo, que as reformas dos sistemas eleitoral e partidário, embora inibam os mecanismos da política tradicional, não os eliminam.

34. Por exemplo, durante a crise asiática, o ministro da Fazenda do Brasil indicou a necessidade de se definir áreas de interesse público, não sujeitas ao jogo político e aos interesses partidários, como a defesa do Real, isto é, da estabilidade da moeda, de tal forma que as medidas necessárias para enfrentar a situação de crise possam ser prontamente tomadas.

35. No importante artigo “Democracy with Adjectives: Conceptual Issues in the Study of Democratization", Collier e Levitsky referem-se a subtipos "diminuídos" de democracia, usados na literatura de democratização para evitar o "esticamento conceitual". Estes subtipos identificam atributos de democracia que estão faltando e os que estão presentes com relação aos atributos do conceito-raiz (root concept) de democracia, baseado no procedural mínimo de Schumpeter/Dahl. Porque especificam os atributos que estão faltando, a diferenciação aumenta. Assim, os subtipos diminuídos, de fato, referem-se a um conjunto de casos diferentes dos casos a que se refere a definição básica de democracia (Collier e Levitsky, 1997:438-439).

36. Este é o termo usado na versão em português de "Democracia Delegativa" (Novos Estudos Cebrap, no 31, outubro de 1991). Na versão em inglês do artigo, publicada em Diamond e Plattner (1996a), O'Donnell usa a expressão "new species".

37. Comunicação oral, seminário Models and Conceptualizations of Political Change: Applications to Latin America, Berkeley, outono de 1997.

38. A temida opção da volta ao autoritarismo não é importante para o argumento que se quer desenvolver aqui.

39. A questão da promoção da democracia como parte da política externa americana é tratada classicamente por Robert Packeham (1973). A literatura recente sobre democratização tem tratado o tema sob o prisma da eficácia da pressão externa por democracia, sob várias formas, na promoção e consolidação de regimes democráticos (cf., p. ex., Farer, 1996; Lowenthal, 1991; Muravchik, 1992; Nelson e Eglinton, 1996; Stokke, 1995). 
Que Democracia? Uma Visão Conceitual desde a Perspectiva dos Países...

40. Essa é uma discussão relevante que, entretanto, foge ao escopo deste trabalho.

41. Cf. O'Donnell (1997c) que, de forma semelhante, exorta os estudiosos de democracia a uma postura não teleológica e a construir tipologias positivas dos diferentes tipos de democracia.

42. O’Donnell (1997c:52) assim se expressa a esse respeito: "Acreditamos que democracia, mesmo na forma bastante modesta de poliarquia é sem dúvida nenhuma preferível ao sortimento de regimes autoritários que ela substituiu" (tradução livre).

\section{REFERÊNCIAS BIBLIOGRÁFICAS}

AGUERO, Felipe. (1992), “The Military and the Limits to Democratization”, in S. Mainwaring, G. A. O’Donnell e J. S. Valenzuela (eds.), Issues in Democratic Consolidation: The New South American Democracies in Comparative Perspective. Notre Dame, IN, University of Notre Dame Press.

_ (1997), "Toward Civilian Supremacy in South America", in L. Diamond e M. Plattner (eds.), Consolidating the Third Wave Democracies: Themes and Perspectives. Baltimore/London, The Johns Hopkins University Press.

ALVAREZ, Michael, CHEIBUB, José Antônio, LIMONGI, Fernando e PRZEWORSKI, Adam. (1996), "Classifying Political Regimes". Studies in Comparative International Development, vol. $31, \mathrm{n} \div 2$.

CASTrO SANTOS, Maria Helena de. (1993), Política e Políticas de uma Energia Alternativa: O Caso do Proálcool. Rio de Janeiro, Ed. Notrya/AnPocs.

_. (1997), “Governabilidade, Governança e Democracia: Criação de Capacidade Governativa e Relações Executivo-Legislativo no Brasil Pós-Constituinte”. Dados, vol. $40, \mathrm{n}^{\circ} 3$.

COLLIER, David (ed.). (1979), The New Authoritarianism in Latin America. Princeton, NJ, Princeton University Press.

_ (1993), "The Comparative Method", in I. Finifter (ed.), Political Science: The State of the Discipline II. Washington, D.C., American Political Science Association.

_ e LEVITSKY, Steven. (1997), "Democracy with Adjectives: Conceptual Issues in the Study of Democratization". World Politics, vol. 49, nํㅡ.

COLLIER, Ruth. (1999), Toward Democracy: The Working Class and Elites in Western Europe and South America. Cambridge, Cambridge University Press.

CONAGHAN, Catherine M. (1992), "Capitalists, Technocrats, and Politicians: Policy Making and Democracy in Central Andes", in S. Mainwaring, G. A. O'Donnell e J. S. Valenzuela (eds.), Issues in Democratic Consolidation: The New South American De- 


\section{Maria Helena de Castro Santos}

mocracies in Comparative Perspective. Notre Dame, IN, University of Notre Dame Press.

DAHL, Robert. (1956), Preface to Democratic Theory. Chicago/London, The University of Chicago Press.

_. (1971), Polyarchy. New Haven/London, Yale University Press.

_. (1982), Dilemmas of Pluralist Democracy. New Haven/London, Yale University Press.

_. (1989), Democracy and its Critics. New Haven/London, Yale University Press.

_ e LINDBLOM, Charles. (1953), Politics, Economics and Welfare (2 ${ }^{\mathrm{a}}$ ed.). Chicago, University of Chicago Press.

DIAMOND, Larry. (1996a), “The Paradoxes of Democracy", in L. Diamond e M. F. Plattner (eds.), The Global Resurgence of Democracy. Baltimore/London, The Johns Hopkins University Press.

_ (1996b), "Toward Democratic Consolidation", in L. Diamond e M. F. Plattner (eds.), The Global Resurgence of Democracy. Baltimore/London, The Johns Hopkins University Press.

_. (1996c), "Is the Third Wave Over ?". Journal of Democracy, vol. 7, no 3.

_. (1999), Developing Democracy: Toward Consolidation. Baltimore/London, The Johns Hopkins University Press.

_. (2000), "The End of the Third Wave and the Start of the Fourth", in M. F. Plattner e J. C. Espada (eds.), The Democratic Invention. Baltimore/London, The Johns Hopkins University Press.

_ e PLATTNER, Marc F. (eds.). (1996a), Civil-Military Relations and Democracy. Baltimore/London, The Johns Hopkins University Press.

_ (eds.). (1996b), The Global Resurgence of Democracy. Baltimore/London, The Johns Hopkins University Press.

_ (eds.). (1996c), Economic Reform and Democracy. Baltimore/London, The Johns Hopkins University Press.

DINIZ, Eli. (1997), Crise, Reforma do Estado e Governabilidade. Rio de Janeiro, Fundação Getulio Vargas Editora.

FARER, Tom (ed.). (1996), Beyond Sovereignty: Collectively Defending Democracy in the Americas. Baltimore/London, The Johns Hopkins University Press.

FREEDOM HOUSE. (1996-97, 1997-98 e 1999-00), Freedom in the World: The Annual Survey of Political Rights and Civil Liberties. New York, Freedom House.

FUKUYAMA, Francis. (1989), “The End of History?”. The National Interest, no 16, Summer.

_. (1991), "Liberal Democracy as a Global Phenomenon". PS: Political Science and Politics, $\mathrm{n}^{-} 4$.

_. (1996), "The Primacy of Culture", in L. Diamond e M. F. Plattner (eds.), The Global Resurgence of Democracy. Baltimore/London, The Johns Hopkins University Press.

764

Revista Dados 


\section{Que Democracia? Uma Visão Conceitual desde a Perspectiva dos Países...}

GEDDES, Barbara. (1995), “Challenging the Conventional Wisdom”, in L. Diamond e M. F. Plattner (eds.), Economic Reform and Democracy. Baltimore/London, The Johns Hopkins University Press.

HAGGARD, Stephan e KAUFMAN, Robert. (1994), “The Challenges of Consolidation". Journal of Democracy, vol. 5, no 4 .

. (1995), The Political Economy of Democratic Transitions. Princeton, NJ, Princeton University Press.

HAGOPIAN, Frances. (1992), "The Compromised Consolidation: The Political Class in the Brazilian Transition", in S. Mainwaring, G. A. O'Donnell e J. S. Valenzuela (eds.), Issues in Democratic Consolidation: The New South American Democracies in Comparative Perspective. Notre Dame, IN, University of Notre Dame Press.

_. (1996), Traditional Politics and Regime Change in Brazil. Cambridge, Cambridge University Press.

HOROWITZ, Donald. (1996), “Comparing Democratic Systems”, in L. Diamond e M. F. Plattner (eds.), The Global Resurgence of Democracy. Baltimore/London, The Johns Hopkins University Press.

HUNTER, Wendy. (1997), Eroding Military Influence in Brazil: Politicians against Soldiers. Chapel Hill, University of North Carolina Press.

HUNTINGTON, Samuel. (1968), Political Order in Changing Societies. New Haven/London, Yale University Press.

_. (1974), Documento (sem título) preparado para a Wingspread Conference, 17-18 de abril.

_. (1991), The Third Wave: Democratization in the Late Twentieth Century. Norman, University of Oklahoma Press.

_. (1996a), The Clash of Civilizations and the Remaking of World Order. New York, Simon and Schuster.

_. (1996b), "Democracy's Third Wave”, in L. Diamond e M. F. Plattner (eds.), The Global Resurgence of Democracy. Baltimore/London, The Johns Hopkins University Press.

JOWITT, Ken. (1996), “The New World Disorder”, in L. Diamond e M. F. Plattner (eds.), The Global Resurgence of Democracy. Baltimore/London, The Johns Hopkins University Press.

KARL, Terry Lynn. (1986), “Imposing Consent? Electoralism versus Democratization in El Salvador", in P. Drake e E. Silva (eds.), Elections and Democratization in Latin America, 1980-1985. San Diego, Center for Iberian and Latin American Studies e Center for U.S. Studies, University of California at San Diego.

_. (1990), "Dilemmas of Democratization in Latin America". Comparative Politics, vol. $23, \mathrm{n}^{\mathrm{0}} 1$.

_. (1995), “The Hybrid Regimes of Central America”. Journal of Democracy, no 6. 


\section{Maria Helena de Castro Santos}

KRÓL, Marcin. (1996), “Where East Meets West", in L. Diamond e M. F. Plattner (eds.), The Global Resurgence of Democracy. Baltimore/London, The Johns Hopkins University Press.

LIJPHART, Arend. (1996a), "Constitutional Choices for New Democracies", in L. Diamond e M. F. Plattner (eds.), The Global Resurgence of Democracy. Baltimore/London, The Johns Hopkins University Press.

_. (1996b), "Double-Checking the Evidence", in L. Diamond e M. F. Plattner (eds.), The Global Resurgence of Democracy. Baltimore/London, The Johns Hopkins University Press.

. (1999), Patterns of Democracy: Governments Forms and Performances in Thirty-Six Countries. New Haven/London, Yale University Press.

LINZ, Juan. (1996a), "The Perils of Presidentialism”, in L. Diamond e M. F. Plattner (eds.), The Global Resurgence of Democracy. Baltimore/London, The Johns Hopkins University Press.

. (1996b), “The Virtues of Parlamentarism”, in L. Diamond e M. F. Plattner (eds.), The Global Resurgence of Democracy. Baltimore/London, The Johns Hopkins University Press.

_ e STEPAN, Alfred. (1996), Problems of Democratic Consolidation: Southern Europe, South America, and Post-Communist Europe. Baltimore/London, The Johns Hopkins University Press.

LIPSET, Seymour M. (1996), “The Centrality of Political Culture”, in L. Diamond e M. F. Plattner (eds.), The Global Resurgence of Democracy. Baltimore/London, The Johns Hopkins University Press.

LOWENTHAL, Abraham F. (1991), Exporting Democracy: The United States and Latin America. Baltimore/London, The Johns Hopkins University Press.

LOWI, Theodore. (1964), "American Business, Public Policy, Case-Studies, and Political Theory". World Politics, vol. XVI, no 4 .

MAINWARING, Scott. (1992), “Transitions to Democracy and Democratic Consolidation: Theoretical and Comparative Issues", in S. Mainwaring, G. A. O'Donnell e J. S. Valenzuela (eds.), Issues in Democratic Consolidation: The New South American Democracies in Comparative Perspective. Notre Dame, IN, University of Notre Dame Press.

MALLOY, James (ed.). (1977), Authoritarianism and Corporatism in Latin America. Pittsburgh, The University of Pittsburgh Press.

_. (1993), “Política Econômica e o Problema de Governabilidade Democrática nos Andes Centrais", in L. Sola (ed.), Estado, Mercado e Democracia: Política e Economia Comparada. São Paulo, Paz e Terra.

MARAVALL, José María. (1995), "The Myth of the Authoritarian Advantage", in L. Diamond e M. F. Plattner (eds.), Economic Reform and Democracy. Baltimore/London, The Johns Hopkins University Press.

METTENHEIM, Kurt von. (1999), A Presidência Brasileira e a Separação dos Poderes. Trabalho apresentado no XXIII Encontro Anual da Associação Nacional de

\section{6}

Revista Dados 


\section{Que Democracia? Uma Visão Conceitual desde a Perspectiva dos Países...}

Pós-Graduação e Pesquisa em Ciências Sociais — ANPocs, Caxambu, MG, 19-23 de outubro.

MUNCK, Gerardo. (1996), “Desagregating Political Regime: Conceptual Issues in the Study of Democratization". Working Paper, no 228, The Kellogg Institute.

MURAVCHIK, Joshua. (1992), Exporting Democracy: Fulfilling America's Destiny. Washington, D.C., The AEI Press.

NAÍM, Moises. (1995), “Latin America: The Second Stage of Reform”, in L. Diamond e M. F. Plattner (eds.), Economic Reform and Democracy. Baltimore/London, The Johns Hopkins University Press.

NELSON, Joan. (1995), "Linkages between Politics and Economics", in L. Diamond e M. F. Plattner (eds.), Economic Reform and Democracy. Baltimore/London, The Johns Hopkins University Press.

_ e EGLINTON, Stephanie J. (1996), “The International Donor Community: Conditioned Aid and the Promotion and Defense of Democracy", in T. Farer (ed.), Beyond Sovereignty: Collectively Defending Democracy in the Americas. Baltimore/London, The Johns Hopkins University Press.

O'DONNELL, Guillermo. (1977), "Corporatism and the Question of the State", in J. Malloy (ed.). Authoritarianism and Corporatism in Latin America. Pittsburgh, The University of Pittsburgh Press.

. (1979), "Tensions in the Bureaucratic-Authoritarian State and the Question of Democracy", in D. Collier (ed.), The New Authoritarianism in Latin America. Princeton, NJ, Princeton University Press.

_. (1992), "Transitions, Continuities, and Paradoxes", in S. Mainwaring, G. O'Donnell e L. S. Valenzuela (eds.), Issues in Democratic Consolidation: The New South American Democracies in Comparative Perspective. Notre Dame, IN, University of Notre Dame Press.

. (1996a), "Delegative Democracy”, in L. Diamond e M. F. Plattner (eds.), The Global Resurgence of Democracy. Baltimore/London, The Johns Hopkins University Press.

__. (1996b), “Uma Outra Institucionalização”. Lua Nova, no 37.

_. (1997a), Horizontal Accountability and New Polyarchies. Trabalho apresentado na conferência Institutionalizing Horizontal Accountability, Institute for Advanced Studies of Vienna and the International Forum for Democratic Studies, Vienna, junho. (Publicado em Lua Nova, no 44, 1998, com o título, "Accountability Horizontal e as Novas Poliarquias").

. (1997b), Polyarchies and (Un)Rule of Law in Latin America. Trabalho apresentado no Encontro Anual da American Political Science Association - APSA, Washington, D.C., 28-31 de agosto. (Publicado em português como capítulo em J. Méndez, G. O’Donnell e P. S. Pinheiro (orgs.), Democracia, Violência e Injustiça: O Não-Estado de Direito na América Latina, Rio de Janeiro, Editora Paz e Terra, com o título "Poliarquias e a (In)efetividade da Lei na América Latina: Uma Conclusão Parcial".) 


\section{Maria Helena de Castro Santos}

_. (1997c), “Illusions about Consolidation”, in L. Diamond et alii (eds.), Consolidating the Third Wave Democracies: Themes and Perspectives. Baltimore/London, The Johns Hopkins University Press.

_ e SCHMITTER, Philippe. (1986), Tentative Conclusions about Uncertain Democracies. Baltimore/London, The Johns Hopkins University Press.

PACKEHAM, Robert. (1973), Liberal America and the Third World. Princeton, NJ, Princeton University Press.

PAIXÃO, Antônio L. e CASTRO SANTOS, Maria Helena de. (1988), “O Álcool Combustível e a Pecuária de Corte: Fragmentação e Porosidade no Estado Burocrático-Autoritário". Revista Brasileira de Ciências Sociais, vol. 3, no 7, junho.

PATEMAN, Carole. (1970), Participation and Democratic Theory. Cambridge, Cambridge University Press.

PIO, Carlos. (1997), “Liberalização do Comércio: Padrões de Interação entre Elites Burocráticas e Atores Sociais", in E. Diniz e S. Azevedo (orgs.), Reforma do Estado e Democracia no Brasil: Dilemas e Perspectivas. Brasília, Ed. UnB/ENAP.

_. (2001), A Construção Política da Economia de Mercado no Brasil: Estabilização Econômica e Liberalização Comercial (1985-1995). Tese de Doutorado em Ciência Política, IUPERJ.

PLATTNER, Marc F. (1996), “The Democratic Moment”, in L. Diamond e M. F. Plattner (eds.), The Global Resurgence of Democracy. Baltimore/London, The Johns Hopkins University Press.

PRZEWORSKI, Adam e LIMONGI, Fernando. (1997), “Modernization: Theories and Facts". World Politics, vol. 49, no 2.

PRZEWORSKI, Adam, ALVAREZ, Michael, CHEIBUB, José Antônio e LIMONGI, Fernando. (1996), “What Makes Democracies Endure?”. Journal of Democracy, vol. 7, no⒈

PUTNAM, Robert. (1995), “Bowling Alone: America's Declining Social Capital”. Journal of Democracy, vol. 6, nำ 1 .

QUADE, Quentin. (1996), "PR and Democratic Statecraft", in L. Diamond e M. F. Plattner (eds.), The Global Resurgence of Democracy. Baltimore/London, The Johns Hopkins University Press.

REMMER, Karen. (1986), “The Politics of Economic Stabilization: IMF Standby Programs in Latin America, 1954-1984". Comparative Politics, vol. 19, № 1.

RIAL, Juan. (1992), "Armies and Civil Society in Latin America”, in L. Diamond e M.F. Plattner (eds.), Civil-Military Relations and Democracy. Baltimore/London, The Johns Hopkins University Press.

ROSE, Richard. (1996), "Postcommunism and the Problem of Trust", in L. Diamond e M. F. Plattner (eds.), The Global Resurgence of Democracy. Baltimore/London, The Johns Hopkins University Press.

ROWEN, Henry S. (1996), "The Tide Underneath the Third Wave", in L. Diamond e M. F. Plattner (eds.), The Global Resurgence of Democracy. Baltimore/London, The Johns Hopkins University Press. 
Que Democracia? Uma Visão Conceitual desde a Perspectiva dos Países...

RUA, Maria das Graças. (1997), “A Independência do Banco Central: Administração ou Política?", in E. Diniz e S. Azevedo (orgs.), Reforma do Estado e Democracia no Brasil: Dilemas e Perspectivas. Brasília, Editora UnB/ENAP.

__ e AGUIAR, Alessandra T. (1995), “A Política Industrial no Brasil, 1985-1992: Políticos, Burocratas e Interesses Organizados no Processo de Policy-Making". Planejamento e Políticas Públicas, ํㅡㄴ 12 .

SARTORI, Giovanni. (1970), "Concept Misformation in Comparative Politcs". The American Political Science Review, vol. LXIV, ํㅡㄴ 4

SCHMITTER, Phillipe. (1992), "Interest Systems and the Consolidation of Democracies", in L. Diamond e G. Marks (eds.), Reexamining Democracy. Newbury Park, CA, Sage.

_ e KARL, Terry Lynn. (1996), “What Democracy Is ... and Is Not”, in L. Diamond e M. F. Plattner (eds.), The Global Resurgence of Democracy. Baltimore/London, The Johns Hopkins University Press.

_. (s/d), Essaying the Consolidation of Democracy: Comparative Reflections on Recent Efforts in Southern and Eastern Europe, South and Central America. European University Institute and Stanford University. Manuscrito.

SCHMITTER, Philippe e SANTISO, Javier. (1997), Three Temporal Dimensions to the Consolidation of Democracy. Instituto Universitario Europeo e Institut d'Études Politiques de Paris. Manuscrito.

SCHUMPETER, Josef. (1943), Capitalism, Socialism, and Democracy. New York, Harper and Row, caps. XXI e XXII.

SHARE, Donald e MAINWARING, Scott. (1988), “Transições através da Negociação: A Democratização no Brasil e na Espanha", in W. Selcher (ed.), A Abertura Política no Brasil: Dinâmica, Dilemas e Perspectivas. São Paulo, Ed. Convívio.

STOKKE, Olav (ed.). (1995), Aid and Political Conditionality. London, Frank Cass.

WORLD BANK. (1992), Governance and Development. Washington, World Bank, abril. 
Maria Helena de Castro Santos

\author{
ABSTRACT \\ Which Democracy? A Conceptual View from the Developing Countries \\ Perspectives
}

Is the western liberal model of democracy adequate to analyze the new political regimes of the Third Wave of Democracy? After reviewing the recent literatures on democratization and economic reform, I refer to their signifying concepts, namely, governability, governance and democracy, as well as to their implicit normative biases. I give especial attention to the concept of democracy as used by those literatures, based on the so-called procedural minimum (Schumpeter/Dahl). Considered too minimum by leading authors, this definition has been expanded to include "precising" attributes. Rather than augmenting even further Dahl's list, I here propose to include in the regime change investigation the characteristics of the decision-making process, as an analytical tool to characterize the new political systems on their own terms. I claim that this approach better exams the more or less democratic character of the building regimes in the period between elections, bringing to the fore the question of vertical accountability of the bureaucracies, issue unsatisfactorily treated by democracy theorists. The policy process approach allows as well for the identification of different types of democracy which differently combine characteristics of decision-making. Finally, with reference to the Brazilian case, I consider the type of political regime the emerging countries are able or willing to build, offering some working hypotheses to analyze them.

Key words: democracy; new democracies; governability; governance; decision-making process

\title{
RÉSUMÉ \\ Quelle Démocratie? Une Optique à Partir de la Perspective des Pays en Voie de Développement
}

Le modèle de démocratie libérale occidentale serait-il approprié à une analyse des nouveaux régimes politiques de la Troisième Vague démocratique? Dans cet article, après une récapitulation de la littérature sur la démocratisation et la réforme économique, on fait état de quelques concepts significatifs: gouvernabilité, gouvernance et démocratie, ainsi que de leurs biais normatifs implicites. On a examiné surtout le concept de démocratie qui se fonde sur le procedural minimum de Schumpeter/Dahl. Bien 
Que Democracia? Uma Visão Conceitual desde a Perspectiva dos Países...

que considérée trop étroite par des auteurs importants, cette définition de démocratie, qui a reçu des qualificatifs la précisant davantage, a gagné du terrain. Au lieu d'en rajouter d'autres à la liste de Dahl, on propose ici qu'on tienne compte, lors de l'étude des régimes en changement, des caractéristiques du processus de décision en tant qu'instrument analytique à même d'identifier les nouveaux systèmes politiques selon leurs propres termes. Cette approche semble plus pertinente pour l'examen du caractère plus ou moins démocratique des régimes en construction dans les périodes entre les élections, faisant ressortir la question du contrôle vertical des bureaucraties, insuffisamment traitée par la théorie démocratique. On réussit à identifier aussi différents types de démocratie qui associent de façon diverse les caractéristiques de leur processus de décision. Enfin, à partir du cas brésilien, on présente quelques considérations sur le type de régime politique que les pays émergents sont capables de construire, ou se disposent à construire, tout en leur suggérant quelques hypothèses de travail et d'analyse.

Mots-clé: démocratie; nouvelles démocraties; gouvernabilité; gouvernance; processus de décision 